\title{
The PreVOCA experiment: modeling the lower troposphere in the Southeast Pacific
}

\author{
M. C. Wyant ${ }^{1}$, R. Wood ${ }^{1}$, C. S. Bretherton ${ }^{1}$, C. R. Mechoso $^{2}$, J. Bacmeister ${ }^{3}$, M. A. Balmaseda ${ }^{4}$, B. Barrett ${ }^{5}$, \\ F. Codron $^{6}$, P. Earnshaw ${ }^{7}$, J. Fast $^{8}$, C. Hannay ${ }^{9}$, J. W. Kaiser ${ }^{4}$, H. Kitagawa ${ }^{10}$, S. A. Klein ${ }^{11}$, M. Köhler ${ }^{4}$,

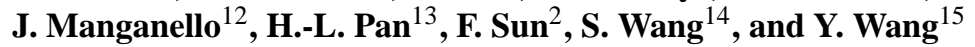 \\ ${ }^{1}$ Department of Atmospheric Sciences, University of Washington, Seattle, WA, USA \\ ${ }^{2}$ Department of Atmospheric and Oceanic Sciences, University of California, Los Angeles, Los Angeles, CA, USA \\ ${ }^{3}$ Global Modeling and Assimiliation Office, NASA Goddard Space Flight Center, Greenbelt, MD, USA \\ ${ }^{4}$ Research Department, European Center for Medium-Range Weather Forecasts, Reading, UK \\ ${ }^{5}$ Department of Geophysics, University of Chile, Santiago, Chile \\ ${ }^{6}$ Université Pierre et Marie Curie, Laboratoire de Meteorologie Dynamique, Paris, France \\ ${ }^{7}$ Met Office, Exeter, Devon, UK \\ ${ }^{8}$ Atmospheric Sciences and Global Change, Pacific Northwest National Laboratory, Richland, WA, USA \\ ${ }^{9}$ Climate and Global Dynamics Division, National Center for Atmospheric Research, Boulder, CO, USA \\ ${ }^{10}$ Meteorological College, Japan Meteorological Agency, Tokyo, Japan \\ ${ }^{11}$ Program for Climate Model Diagnosis and Intercomparison, Lawrence Livermore National Laboratory, \\ Livermore, CA, USA \\ ${ }^{12}$ Center for Ocean-Land-Atmosphere Studies, Calverton, MD, USA \\ ${ }^{13}$ Environmental Modeling Center, National Centers for Environmental Prediction, Camp Springs, Maryland, USA \\ ${ }^{14}$ Marine Meteorology Division, Naval Research Laboratory, Monterey, CA, USA \\ ${ }^{15}$ International Pacific Research Center, School of Ocean and Earth Science and Technology, University of Hawaii at Manoa, \\ Honolulu, HI, USA
}

Received: 13 October 2009 - Published in Atmos. Chem. Phys. Discuss.: 11 November 2009

Revised: 22 April 2010 - Accepted: 7 May 2010 - Published: 26 May 2010

\begin{abstract}
The Preliminary VOCALS Model Assessment (PreVOCA) aims to assess contemporary atmospheric modeling of the subtropical South East Pacific, with a particular focus on the clouds and the marine boundary layer (MBL). Models results from fourteen modeling centers were collected including operational forecast models, regional models, and global climate models for the month of October 2006. Forecast models and global climate models produced daily forecasts, while most regional models were run continuously during the study period, initialized and forced at the boundaries with global model analyses. Results are compared in the region from $40^{\circ} \mathrm{S}$ to the equator and from $110^{\circ} \mathrm{W}$ to $70^{\circ} \mathrm{W}$, corresponding to the Pacific coast of South
\end{abstract}

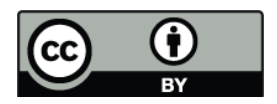

Correspondence to: M. C. Wyant (mwyant@atmos.washington.edu)
America. Mean-monthly model surface winds agree well with QuikSCAT observed winds and models agree fairly well on mean weak large-scale subsidence in the region next to the coast. However they have greatly differing geographic patterns of mean cloud fraction with only a few models agreeing well with MODIS observations. Most models also underestimate the MBL depth by several hundred meters in the eastern part of the study region. The diurnal cycle of liquid water path is underestimated by most models at the $85^{\circ} \mathrm{W} 20^{\circ} \mathrm{S}$ stratus buoy site compared with satellite, consistent with previous modeling studies. The low cloud fraction is also underestimated during all parts of the diurnal cycle compared to surface-based climatologies. Most models qualitatively capture the MBL deepening around 15 October 2006 at the stratus buoy, associated with colder air at $700 \mathrm{hPa}$.

Published by Copernicus Publications on behalf of the European Geosciences Union. 


\section{Introduction}

The atmosphere-ocean system in Southeast Pacific (SEP) is interesting for many reasons. The SEP is a region of significant coastal upwelling and extensive persistent low-level clouds (Klein and Hartmann, 1993), whose sensitivity to climate change is of great interest. The region plays a large role in the El-Nino Southern Oscillation. It also hosts large contrasts of aerosol concentrations, from extremely clean remote maritime conditions to highly polluted conditions downstream of large coastal point sources such as copper smelters.

A major field campaign, the East Pacific Investigation of Climate (EPIC), was conducted in 2001 in the SEP (Raymond et al., 2004; Bretherton et al., 2004). One of EPIC's goals was to examine the interaction of microphysics, clouds, and the marine boundary layer (MBL). At the stratus buoy location $\left(20^{\circ} \mathrm{S} 85^{\circ} \mathrm{W}\right)$ EPIC found a strongly diurnally varying stratocumulus cloud cover with very little cumulus convection (Bretherton et al., 2004). Wood et al. (2002) also reported a strong diurnal variation in liquid water path (LWP) in the region. Other SEP large-scale cloud-related studies have focused on the seasonal cycle of clouds in the region (Klein and Hartmann, 1993), influence of clouds on the coupled climate system (Ma et al., 1996), the effects of topography on subtropical stratocumulus clouds (Xu et al., 2004; Richter and Mechoso, 2004, 2006), effects of the diurnal heating over the Andes on the MBL (Garreaud et al., 2001; Garreaud and Munoz, 2004; Wood et al., 2009), sub-seasonal MBL variability (Xu et al., 2005), and inter-annual variations of MBL depth (Zuidema et al., 2009).

Despite advances in observing and understanding the SEP, general circulation models (GCMs) typically do not represent this region well. The recent study of Hannay et al. (2009) compared forecasts of the Geophysical Fluid Dynamics Laboratory (GFDL) and the National Center for Atmospheric Research (NCAR) Community Atmospheric Model (CAM) GCMs and the ECMWF forecast model to six days of October 2001 EPIC observations at the stratus buoy. All models produced a shallower boundary layer than observed and had amplitude and phase errors in the diurnal cycle of LWP compared to observations, while the ECMWF model performed better than the GCMs in terms of cloud prediction.

The SEP is also the focus of VOCALS (VAMOS Ocean Cloud-Atmosphere-Land Study). In preparation for the VOCALS Regional Experiment (REx), which took place from mid-October through mid-November 2008, we organized an assessment of current atmospheric modeling capability. PreVOCA (the Preliminary VOCALS model Assessment) compares a large and diverse collection of models simulating the SEP during the period of October 2006. These include operational forecast models, regional models, and global climate models. The main goals are to understand current model biases and their implications for forecasting and mod- eling during REx. Available for evaluating the models are ship-based observations from National Oceanographic and Atmospheric Administration (NOAA) and the Woods Hole Oceanographic Institution (WHOI) cruises from the coast to the stratus buoy at $20^{\circ} \mathrm{S} 85^{\circ} \mathrm{W}$, a large suite of satellite measurements, and operational meteorological analysis and reanalysis. The month of October 2006 was chosen because of the availability of diverse satellite and ship observations and because it matches the seasonal timing of REx.

While a major goal of VOCALS is to study the interaction of aerosols and the marine boundary layer, most of the models participating in PreVOCA have very limited representations of such interactions. Although many models do include the direct radiative effect of aerosol, most do not treat the transport and dispersion of aerosols, but instead use climatological values of aerosol concentration. Most models use single moment bulk microphysical schemes, which do not utilize aerosol information. Because of these limitations, we proceed under the assumption that aerosol impacts are secondary to other physics, and instead focus on the modeling of the MBL and clouds independent of aerosol effects.

We are motivated then by the following questions: Do the models simulate the large scale conditions adequately? Do the models agree on the vertical structure of the MBL? Do the models capture the basic cloud regimes and the MBL sufficiently well? Are the simulations and predictions of such a quality that will support the models use in studies of climate change, aerosol and chemical transport, aerosol indirect effects, and aerosol-cloud interactions?

The outline of this paper is as follows: Sect. 2 describes the setup of PreVOCA and briefly describes the participating models. Additional model details are provided in Appendix A. Section 3 compares the mean monthly prediction of the models with observations. The diurnal cycle of the MBL is examined in Sect. 4, and the response of the MBL region to synoptic variations is discussed in Sect. 5. A concluding discussion is presented in Sect. 6.

\section{Experiment setup}

Our focus is on the maritime region off the west coast of South America from the equator to $40^{\circ} \mathrm{S}$ and from $70^{\circ} \mathrm{W}$ to $110^{\circ} \mathrm{W}$. This region encompasses the stratus buoy at $85^{\circ} \mathrm{W}$ $20^{\circ} \mathrm{S}$ and the region east of it, which was the primary focus of REx.

The diverse collection of models participating in PreVOCA and some of their run parameters are summarized in Table 1 . We loosely categorize the models into three groups: operational, regional, and climate. Operational models are short and medium range forecast models that are run globally and typically involve a data assimilation system. Regional models are run over a more limited area at higher horizontal resolution. They rely on boundary conditions provided by other models, and are most frequently used for mesoscale 
Table 1. Participating models.

\begin{tabular}{|c|c|c|c|c|c|c|}
\hline Name & Type & $\begin{array}{l}\text { Forecast Freq. } \\
\qquad\left[\mathrm{d}^{-1}\right]\end{array}$ & $\begin{array}{l}\text { Forecast Hours } \\
\text { Analyzed }\end{array}$ & $\begin{array}{c}\text { Horizontal } \\
\text { Resolution } \\
\text { (inner domain) } \\
{[\mathrm{km}]}\end{array}$ & $\begin{array}{l}\text { Vertical Levels } \\
\qquad(\sigma>0.8)\end{array}$ & Investigators \\
\hline NRL COAMPS & Regional & 2 & $6-18$ & $81(27)$ & $45(24)$ & S. Wang \\
\hline COLA RSM & Regional & - & - & 50 & $28(8)$ & $\begin{array}{l}\text { J. Manganello } \\
\text { V. Misra }\end{array}$ \\
\hline $\begin{array}{l}\text { IPRC Reg-CM } \\
\text { (IRAM) }\end{array}$ & Regional & - & - & 25 & $28(10)$ & Y. Wang \\
\hline LMDZ & Regional & - & - & $250(50)$ & $38(10)$ & F. Codron \\
\hline $\begin{array}{l}\text { PNNL } \\
\text { (WRF-Chem) }\end{array}$ & Regional & - & - & $45(15)$ & $44(26)$ & $\begin{array}{l}\text { J. Fast } \\
\text { W. Wang } \\
\text { E. Chapman }\end{array}$ \\
\hline U. Chile (WRF) & Regional & - & - & 45 & $43(19)$ & B. Barrett \\
\hline UCLA (WRF) & Regional & - & - & $45(15)$ & $34(8)$ & $\begin{array}{l}\text { F. Sun } \\
\text { A. Hall } \\
\text { X. Qu }\end{array}$ \\
\hline ECMWF OPER & Operational & 2 & $0-12$ & 25 & $91(16)$ & $\begin{array}{l}\text { M. Köhler } \\
\text { J. Kaiser }\end{array}$ \\
\hline ECMWF 5-DAY & Operational & 1 & $48-72$ & 40 & $91(16)$ & M. Köhler \\
\hline $\begin{array}{l}\text { NASA GMAO } \\
\text { GEOS5-DAS }\end{array}$ & Operational & 4 & $0-6$ & 55 & $72(14)$ & J. Bacmeister \\
\hline JMA & Operational & 4 & $24-30$ & 60 & $60(13)$ & $\begin{array}{l}\text { H. Kitagawa } \\
\text { T. Komori } \\
\text { H. Onoda }\end{array}$ \\
\hline NCEP GFS & Operational & 1 & $12-36$ & 38 & $64(15)$ & $\begin{array}{l}\text { H.-L. Pan } \\
\text { R. Sun }\end{array}$ \\
\hline UKMO & Operational & 1 & $12-36$ & 40 & $50(9)$ & $\begin{array}{l}\text { P. Earnshaw } \\
\text { S. Milton }\end{array}$ \\
\hline $\begin{array}{l}\text { ECMWF } \\
\text { Coupled Ens. }\end{array}$ & Climate & - & - & 125 & $62(16)$ & $\begin{array}{l}\text { M. Köhler } \\
\text { M. Balmaseda }\end{array}$ \\
\hline NCAR CAM 3.5/CAM 3.6 UW & Climate & 1 & $48-72$ & 250 & $26(4) / 30(8)$ & C. Hannay \\
\hline GFDL AM2 & Climate & 1 & $48-72$ & 250 & 24(10) & $\begin{array}{l}\text { S. Klein } \\
\text { M. Zhao }\end{array}$ \\
\hline
\end{tabular}

research. The climate models are the atmospheric components of coupled atmosphere-ocean climate models. They have much coarser horizontal resolution than the regional models and are designed to balance global energy budgets. We choose to place the ECMWF coupled ensemble forecast model in the "climate" category, while we place the LMDZ climate model in the "regional" category because it has been run in a mode and resolution in the SEP more typical of regional models than climate models. Typical horizontal resolutions are about $50 \mathrm{~km}$ for regional and operational models, and $250 \mathrm{~km}$ for climate models. Some models use nested grids over the study region with as high as $15 \mathrm{~km}$ resolution. The number of vertical levels varies from 24 to 91 , and all models except for CAM 3.5 have 8 or more levels in the boundary layer. Detailed descriptions of the models including boundary-layer and cloud schemes, microphysics schemes, and aerosol treatments are provided in Appendix A.
There are two simulation modes among the runs presented here: forecast, and continuous. In forecast mode, models made daily forecasts initialized by operational analysis, with a few models making more frequent forecasts (see Table 1). For these runs, a specified subset of forecast hours for each daily run was selected, and these were stitched together to provide a continuous month of model output for comparison with other models.

For each forecast, we expect the vertical structure of the MBL to drift away from the initial analysis towards a modeldependent preferred state, while other supporting features of the forecast do not deviate far from analysis, highlighting biases in the MBL. This approach to identifying parameterization biases applied to GCMs is described in Phillips et al. (2004) and has been used in many recent studies (e.g., Klein et al., 2006; Williamson and Olson, 2007; Boyle et al., 2008; Hannay et al., 2009). 
SST $[K]$

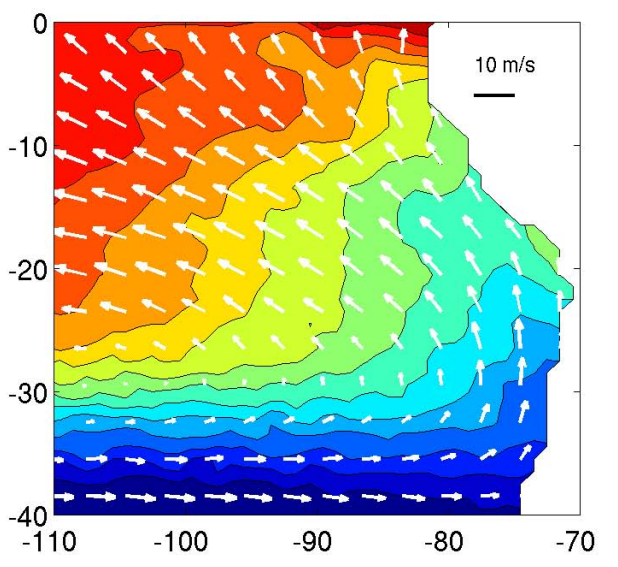

Fig. 1. October 2006 mean AMSR-E SST(K) and QuikSCAT winds $\left(10 \mathrm{~ms}^{-1}\right.$ scale plotted).

In continuous mode, the model fields are initialized by analysis, and then run for the entire month from initial conditions provided by analysis datasets, which also provide time dependent boundary conditions at the edges of the domain. Because the model fields are not re-initialized regularly, greater model biases are expected than in the forecastmode runs.

The models' output is provided every 3 simulated hours. All runs were made with specified SST except for the ECMWF coupled ensemble, which runs coupled to the Hamburg Ocean Primitive Equation model (HOPE, Wolf et al., 1997). The SSTs in the study region typically vary by as much as $0.5 \mathrm{~K}$ across models with discrepancies as large as $1 \mathrm{~K}$ near the coast.

\section{Monthly averages}

We first examine monthly mean fields corresponding to October 2006 to illustrate important aspects of the model simulations of the MBL. For many fields we will show means from a representative subset of models rather than showing all models in order to simplify the presentation.

Figure 1 shows the monthly mean SST from the Advanced Microwave Scanning Radiometer-EOS (AMSR-E) and 10$\mathrm{m}$ wind vectors from Quick Scatterometer (QuikSCAT, used here as processed in Field and Wood, 2007). There is limited blending of 10-m winds with NCEP (National Centers for Environmental Prediction)/NCAR Reanalysis (Kalnay et al., 1996) for missing data. The study region is dominated by the eastern part of the South Pacific subtropical high. Surface southeasterly winds with speeds of $5-9 \mathrm{~ms}^{-1}$ prevail over most the northern half of the region, with southerly winds along coast influenced by the high coastal topography. The winds over most of the study region blow from

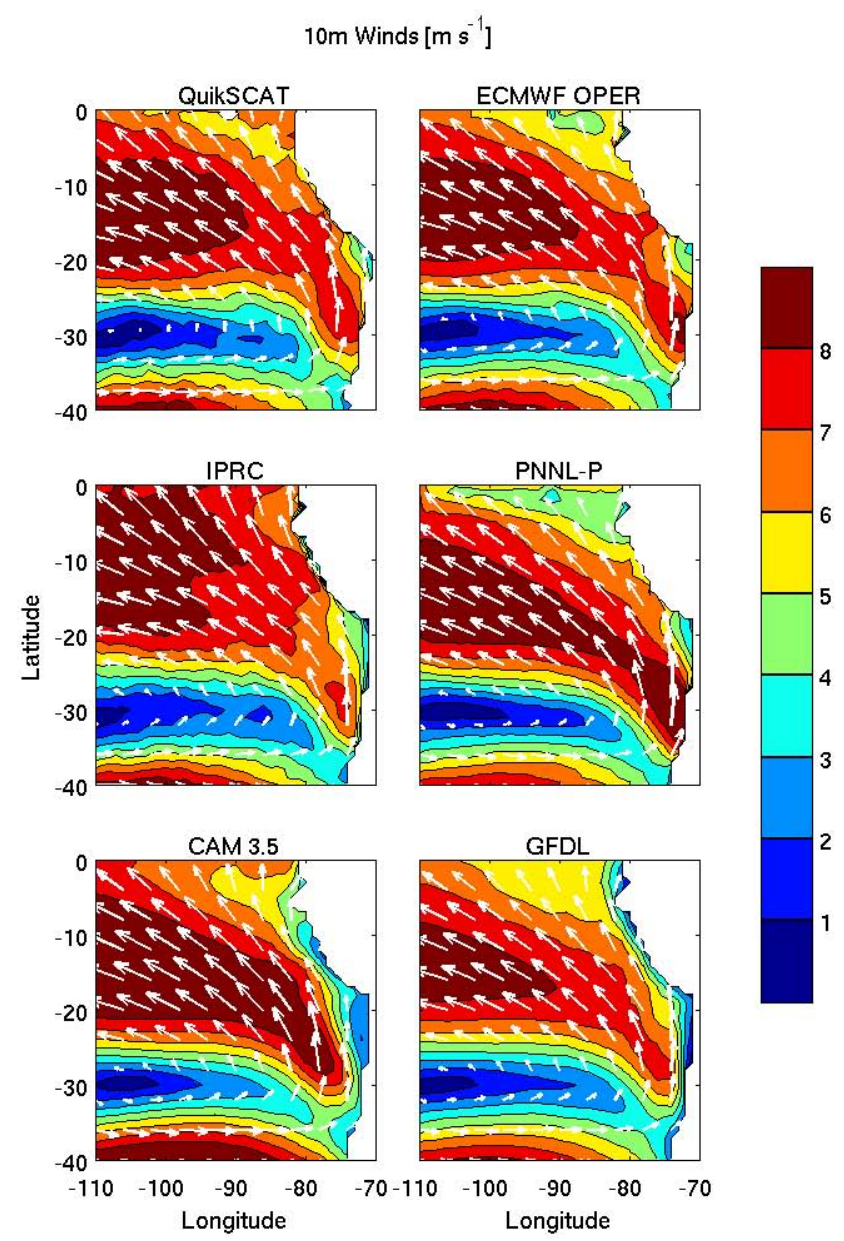

Fig. 2. October 2006 mean $10-\mathrm{m}$ wind speed $\left(\mathrm{ms}^{-1}\right)$ and wind vectors for QuikSCAT (upper left) and a selection of models.

colder to warmer water promoting surface sensible and latent heat flux into the MBL. Those winds are very steady in the north part of the domain, which is free from strong disturbances. In the southern part of the domain, westerlies prevail and eastward propagating disturbances typically pass every few days. In the eastern part of the domain, the lower tropospheric stability is large (Klein and Hartmann, 1993; Wood and Hartmann, 2006), typically associated with very strong inversions at the top of the MBL. Surface precipitation, as estimated by AMSR-E, is light $\left(<0.5 \mathrm{mmd}^{-1}\right)$ across the study region, except south of $30^{\circ} \mathrm{S}$ where mid-latitude disturbances pass, and the modeled surface precipitation is similarly weak $\left(<1 \mathrm{mmd}^{-1}\right)$ for most models.

We compare QuikSCAT 10-m wind direction and speed with a representative selection of models in Fig. 2 (Note that the CAM 3.5 winds are instead from the lowest model grid level at about $64 \mathrm{~m}$ ). The models generally show excellent agreement with the observed surface winds. The mean position of the surface anticyclone is well agreed upon by the models. The weakness of the southerlies along the coast in 
the GCMs is likely due to their coarse horizontal resolution. Note that QuikSCAT observations are assimilated into all of the operational model systems, though the model winds are free to diverge from QuikSCAT during their forecasts. The good agreement of the monthly mean winds with observations and with each other can be attributed to good initialization and the to the relative importance of static large-scale features such as the subtropical high and trade wind circulations which are relatively easy to forecast, compared to the time-dependent features.

Associated with the South Pacific high is broad subsidence. The mean October 2006 subsidence at $850 \mathrm{hPa}$ is shown for several models in Fig. 3. Weak subsidence $\left(\sim 0.03 \mathrm{Pas}^{-1}\right.$ or $\left.\sim 25 \mathrm{hPad}^{-1}\right)$ prevails across most of the study region, with stronger subsidence $\left(>0.05 \mathrm{Pas}^{-1}\right)$ near the Chilean coast at about $30^{\circ} \mathrm{S}$. The main region of model disagreement is the northwest part of the domain, where, for example, the IPRC model has stronger subsidence and the PNNL has slightly weaker subsidence. Note that the domainmean subsidence in regional models is determined by the horizontal winds imposed at the side boundaries. The smallscale spatial variability of monthly-mean subsidence in some models is a common behavior of high-resolution models and depends largely on their numerics and handling of topography.

The models also generally agree on the geographic pattern of mean lower tropospheric stability (not shown). Since the models' SSTs are specified, this is mostly an indicator of agreement of temperature within a few degrees $\mathrm{K}$ at $700 \mathrm{hPa}$.

Despite the generally close agreement among the horizontal wind, vertical velocity, and static stability fields, the models show a large disagreement in their cloud properties. The mean-monthly cloud fraction from the Moderate Resolution Imaging Spectroradiometer (MODIS) and low-cloud fraction for all models are shown in Fig. 4. The MODIS cloud fraction in Fig. 4a (as computed in Field and Wood, 2007) is based on liquid-water retrieval and mostly represents low cloud. It excludes ice cloud which is primarily found south of $30^{\circ} \mathrm{S}$ associated with passing synoptic disturbances. The timing of MODIS data corresponds to about 10:30 a.m. LT, but modeled and observed stratocumulus cloud properties at this time are typically not too far from their 24-h mean.

Model low cloud fractions are computed from the surface to $800 \mathrm{hPa}$ for many of the models, though for several models (CAM, COLA, GFDL, IPRC, and LMDZ) low cloud is computed from the surface to about $700 \mathrm{hPa}$. This difference has minimal consequence north of $25^{\circ} \mathrm{S}$ except for the LMDZ model which has substantial cloud between $700 \mathrm{hPa}$ and $800 \mathrm{hPa}$ that is captured in Fig. 4. Models differ substantially in their cloud overlap assumptions, which are utilized in computing low-cloud fraction in Fig. 4.

The MODIS cloud fraction is $0.8-0.9$ near the coast except for a relatively clear region between $30^{\circ} \mathrm{S}$ and $40^{\circ} \mathrm{S}$ associated with strong subsidence there. Mean cloud fraction decreases moving away from the cloudy part of the coast,

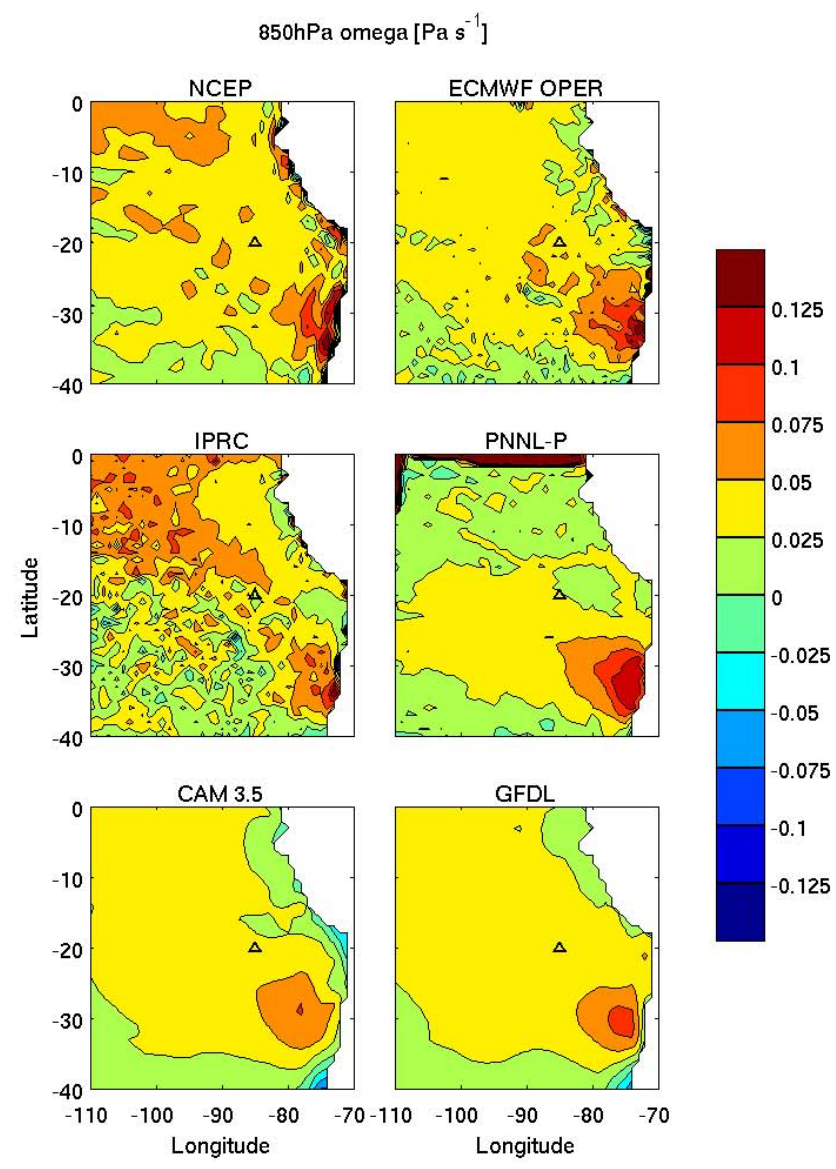

Fig. 3. October 2006 mean subsidence at $850 \mathrm{hPa}\left(\mathrm{Pas}^{-1}\right)$. NCEP and ECMWF analysis is shown in lieu of observed subsidence. The stratus buoy location is indicated with a triangle.

but is still around 0.7 near the stratus buoy, dropping off to 0.4 in the peripheral parts of the study region. The models show a large disparity in cloud fraction despite the similarity in forcing discussed above. A common model problem is too little low cloud near the coast from $30^{\circ} \mathrm{S}$ to the equator, as exemplified in the IPRC and GFDL runs and in the NCEP analysis. The models also vary greatly in the amount of cloud in the north central and northwest part of the study region where trade-cumulus convection is more significant, with many models producing too much cloud compared to MODIS (e.g. PNNL, UCLA, and COLA, LMDZ, and UKMO), and several models too little cloud in this region including IPRC, JMA, UCHILE and especially CAM 3.6 UW. The modeled geographic patterns in the subsidence are generally not reflected in the modeled low-cloud fraction, except for the significant clearing near the coast south of $30^{\circ} \mathrm{S}$ collocated with very strong subsidence. This localized strong subsidence forces the entrainment of very warm and dry above-inversion air into the boundary layer, dissipating cloud. Overall the ECMWF family of models and the UKMO do fairly well in matching the mean MODIS cloud fraction in the region. 
Oct 2006 Low cloud fraction
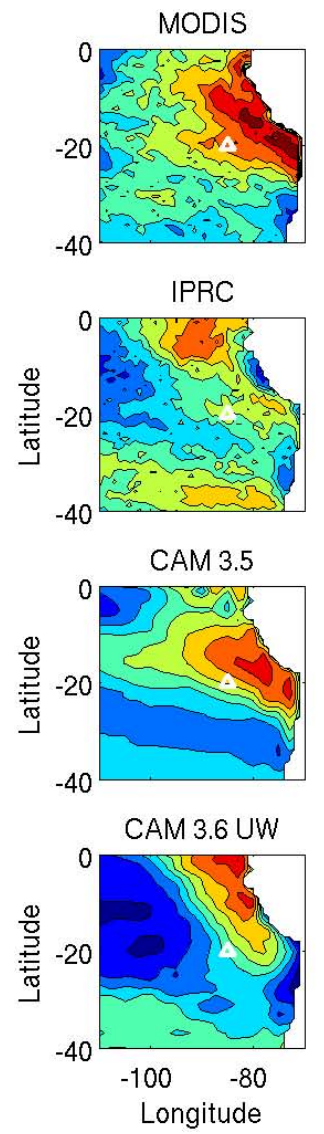

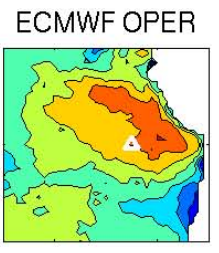

PNNL-P

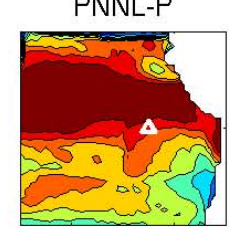

GFDL

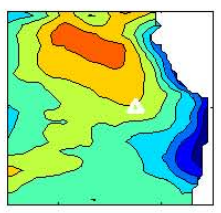

LMDZ

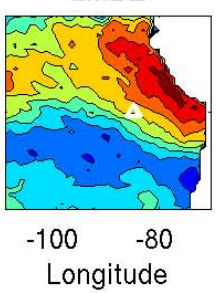

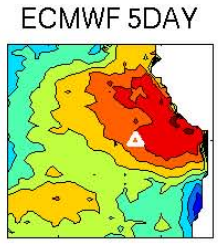

PNNL-M
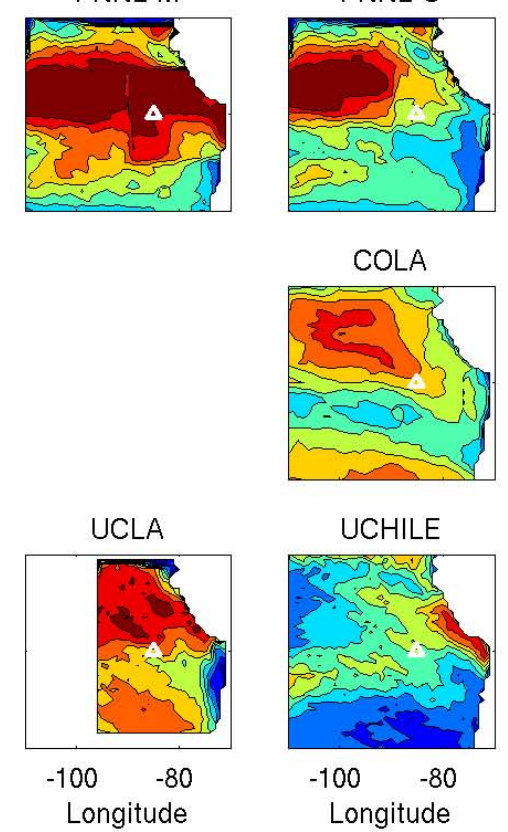
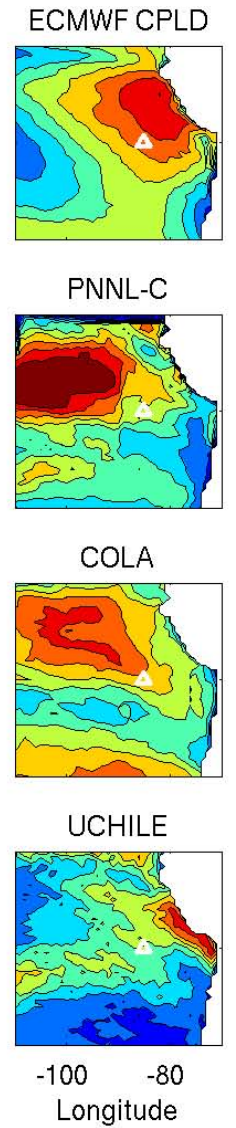
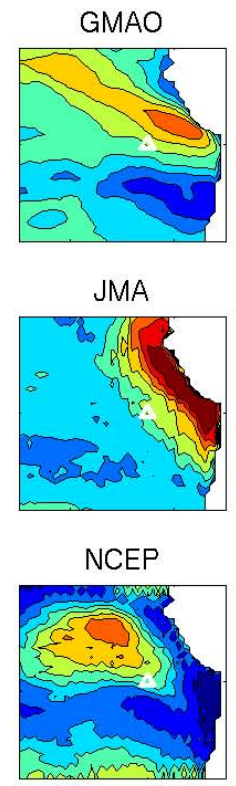

UKMO

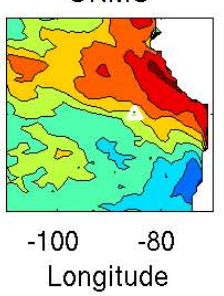

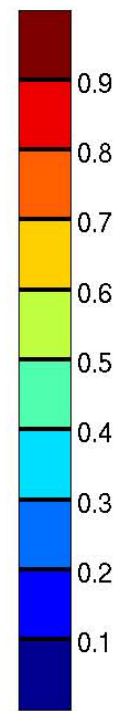

Fig. 4. October 2006 MODIS total cloud fraction (upper left) and modeled monthly-mean low-cloud fraction.

The mean liquid water path (LWP) from several satellites (AMSR-E, TRMM Microwave Instrument (TMI), the Special Sensor Microwave Imager (SSM/I) F13 and F15, L. O'Neill, personal communication, 2009) is compared with the models' total (clear-sky plus cloudy sky) grid-box LWP in Fig. 5. Setting aside the extreme south part of the study region which is influenced by mid-latitude synoptic systems, the observed LWP has a very broad maximum in the north central part of the study region. This is well west of the nearcoastal low-cloud maximum observed in MODIS, and is related to higher SSTs away from the coast. Several models broadly underestimate LWP (e.g. GFDL). Some models underestimate LWP more in the eastern part of the region (e.g. PNNL and NCEP (not shown)), while others underestimate LWP in the western part (CAM 3.5). A few models obtain the basic mean pattern that is qualitatively correct (ECMWF models, GMAO, and UKMO, mostly not shown).

The large model discrepancies in LWP and cloud fraction have substantial implications for the surface energy budget, especially the downwelling shortwave radiation at the surface, a major driver of the SST spatial distribution and sea- sonal cycle (e.g., Colbo and Weller, 2007). Downwelling shortwave radiation is shown in Fig. 6 for almost all models together with the observed monthly mean value from International Satellite Cloud Climatology Project (ISCCP) FD data (Zhang et al., 2004). The downwelling radiation varies between about $220 \mathrm{Wm}^{-2}$ and $300 \mathrm{Wm}^{-2}$ at the stratus buoy location. For each model, geographical biases in downward shortwave radiation compare very closely to those in cloud fraction. This connection is further shown in Fig. 7, which plots each model's mean downward shortwave flux versus low cloud fraction in a $5^{\circ} \times 5^{\circ}$ box centered at $85^{\circ} \mathrm{W} 20^{\circ} \mathrm{S}$. While there are clearly many factors influencing the shortwave radiation reaching the surface, cloud fraction plays a major role. In many models, the substantial under-prediction of clouds from the buoy region eastwards to the South American coast results in very large positive biases (sometimes larger than $100 \mathrm{Wm}^{-2}$ ) in downwelling SW compared to ISCCP. Biases such as these would substantially increase regional SSTs in coupled simulations. 
Model soundings at the stratus buoy are compared next to further explore inter-model differences. Figure $8 \mathrm{com}$ pares the mean October 2006 soundings of specific humidity and potential temperature for the models with an observed climatological sounding. The NOAA/ESRL soundings (see de Szoeke et al., 2009) are the average of data from 169 rawinsondes launched near the stratus buoy during October 2001, 2005, 2006, and 2007 covering 30 total days. The mean sounding indicates a fairly well mixed layer capped by a strong inversion at about $870 \mathrm{hPa}(1450 \mathrm{~m})$ and very stable and dry above-inversion conditions at the buoy.

Of the three categories, the operational model soundings show the least spread and agree fairly well with the ESRL soundings. The MBLs in most models are shallower and moister than the climatology. All of the modelmean-inversions are less sharp than observed. Note that this sharpness is influenced by temporal variability in MBL depth. Above $800 \mathrm{hPa}$ the agreement among operational soundings with the ESRL climatology is generally excellent. The MBLs in the regional models are also generally shallower and slightly moister than the climatology, and the mean-inversions are less sharp than observed, but with much larger spread than the operational models. The larger spread in MBL depths appears to be connected to a similar feature in potential temperatures above $700 \mathrm{hPa}$. The climate model soundings spread is less than that of the regional models, but they also exhibit shallower and moister boundary layers than the climatology. CAM 3.6 UW appears to be an improvement over CAM 3.5 in regard to the latter behavior.

The variation in vertical structure of the boundary layer is also evident in profiles of cloud condensate along $20^{\circ} \mathrm{S}$, shown in Fig. 9, for which we have no direct observational comparison. The transect along $20 \mathrm{~S}$ does not follow a boundary layer trajectory (the boundary layer winds are southeasterly), but it does illustrate the expected deepening of the boundary layer to the west as SST increases. This is similar to the pattern seen with increasing SST in the North East Pacific in observations and models (e.g., Siebesma et al., 2004). Like the North East Pacific, we expect solid stratocumulus near shore transitioning to more broken trade cumulus convection further west.

The vertical distribution of condensate varies substantially between models. CAM 3.5 produces a shallow fog layer near the coast and a shallow and thin cloud layer further west compared to the other models shown. Other previous experiments with CAM suggest that this behavior is not simply due to its coarser vertical resolution than most other models studied here. At the other extreme the IPRC condensate has broad vertical extent and cloud condensate extends above the 700-hPa level west of $100^{\circ} \mathrm{W}$.

The maximum height of condensate is closely tied to the cloud-top height and with the boundary-layer depth. We plot the model-estimated MBL depths along $20^{\circ} \mathrm{S}$ together with a number of observational climatologies in Fig. 10. For each model, the model boundary layer depth is estimated as the

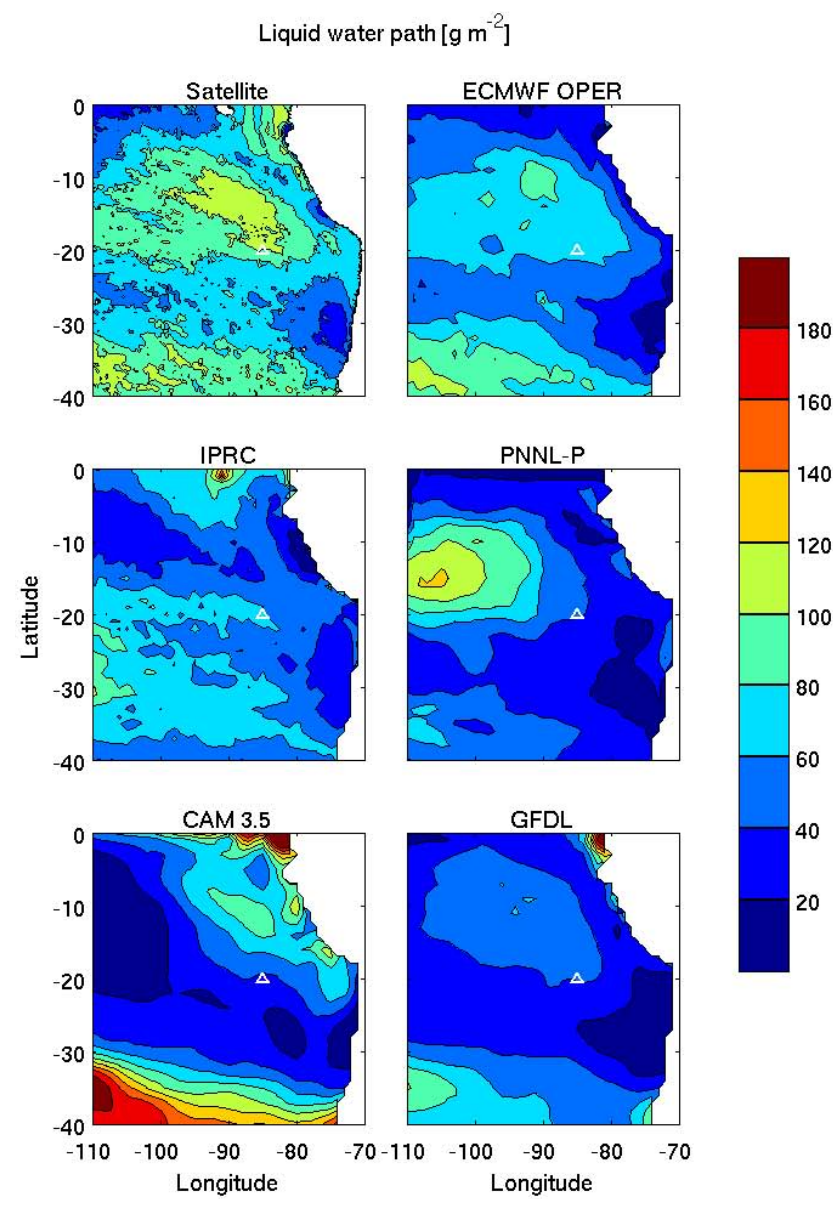

Fig. 5. October 2006 mean satellite liquid water path (upper left, $\left.\mathrm{gm}^{-2}\right)$ and modeled liquid water path $\left(\mathrm{gm}^{-2}\right)$.

top of the highest model level where the relative humidity exceeds $60 \%$. For almost all models, this level is coincident with a sharp decline in cloud condensate with height, and is near the strongest vertical gradient in potential temperature. We use three climatologies of boundary-layer depth or cloud-top height to compare with. Constellation Observing System for Meteorology, Ionosphere, and Climate (COSMIC, Anthes et al., 2008) boundary layer depths are estimated from the height of the largest virtual potential temperature gradient. Because of the relative sparsity of measurements, the values shown are averaged from $15-25^{\circ} \mathrm{S}$. The Cloud-Aerosol Lidar and Infrared Pathfinder Satellite Observation (CALIPSO) cloud-top height climatology (Wu et al., 2008) is created from the Level 2 lidar-based cloud layer product, and is here averaged from $17-23^{\circ} \mathrm{S}$. The MODISderived cloud-top heights are based on cloud-top temperature inferred from measured $11-\mu \mathrm{m}$ radiances (Zuidema et al., 2009) and are averaged here from $19-21^{\circ} \mathrm{S}$. We also plot the mean boundary layer depth estimated from NOAA/ESRL soundings from Fig. 7, using the height where the $\mathrm{RH}=60 \%$. (Ship based radar estimates of boundary-layer depth from 
Oct 2006 SW down surface $\left[W^{-2}\right]$
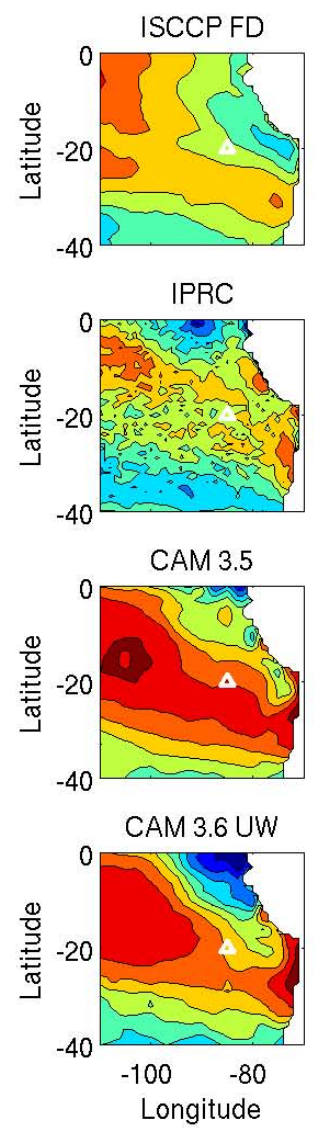

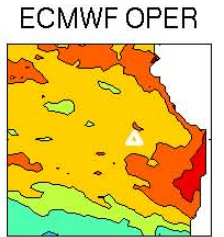

PNNL-P

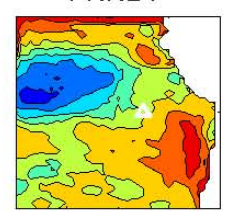

GFDL

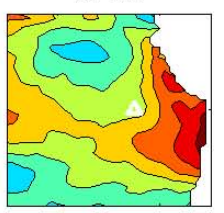

LMDZ

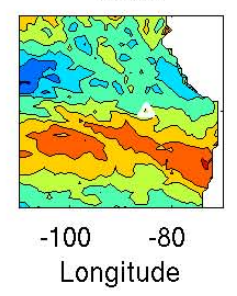

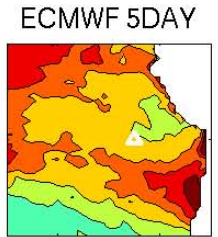

PNNL-M
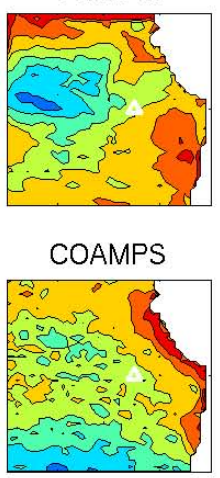

UCLA

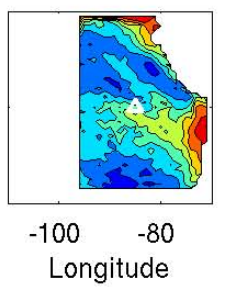

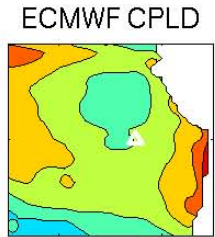

PNNL-C

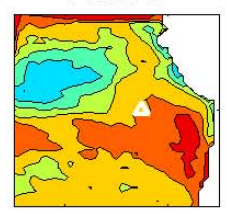

COLA

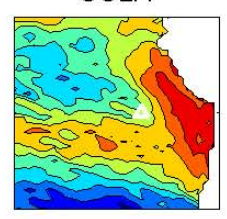

UCHILE

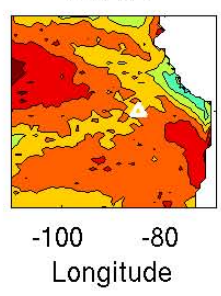

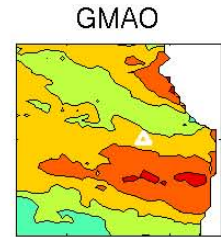
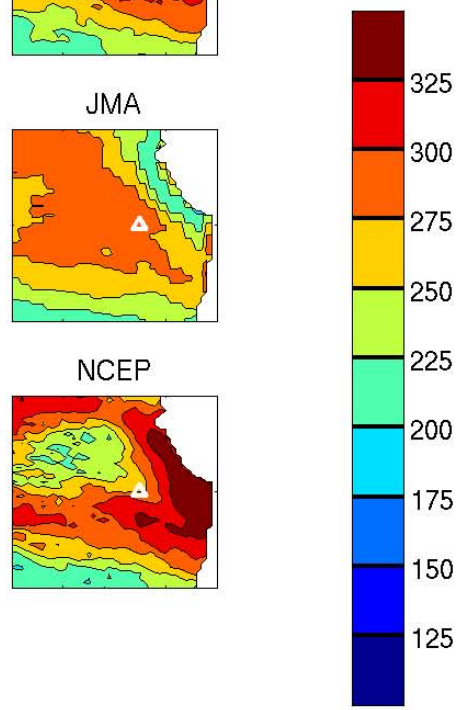

25

Fig. 6. October 2006 mean downwelling SW radiation at the surface from ISSCP and models $\left(\mathrm{Wm}^{-2}\right)$.

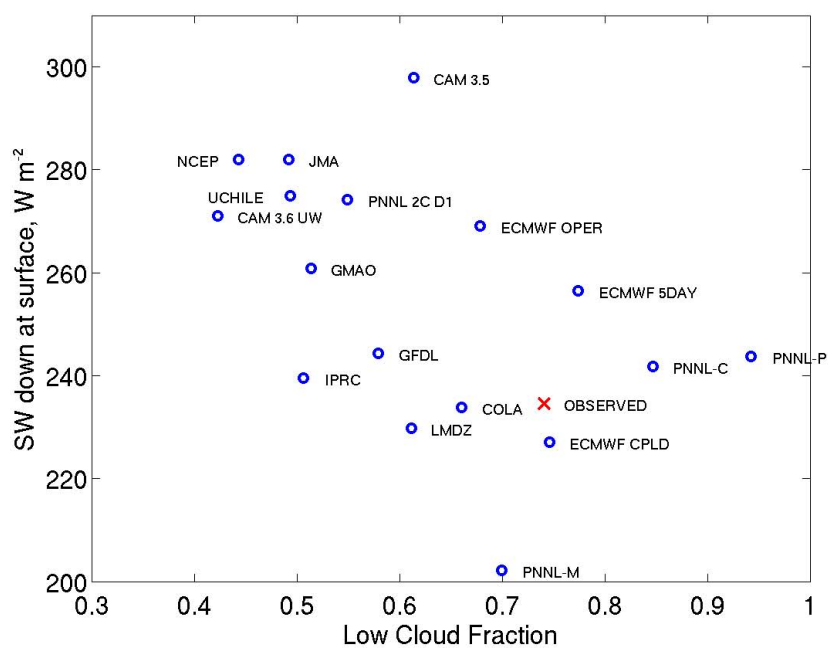

Fig. 7. Mean October 2006 downwelling shortwave radiation at the surface versus low cloud fraction for a $5^{\circ} \times 5^{\circ}$ box centered at $85^{\circ} \mathrm{W} 20^{\circ} \mathrm{S}$. The observed value (red $\mathrm{x}$ ) comes from ISCCP FD data and MODIS liquid cloud fraction. a subset of the days sampled by the soundings have a mean depth about $50 \mathrm{~m}$ less). East of $90^{\circ} \mathrm{W}$, the various observational climatologies agree to within $300 \mathrm{~m}$. West of $90^{\circ} \mathrm{W}$ COSMIC heights are about 300-500 m higher than the other observed estimates, possibly because cloud-top height begins to diverge from inversion base height in the trade-wind MBL. Comparison of MODIS and CALIPSO mean cloudtop heights with model boundary-layer depths west of $90^{\circ} \mathrm{W}$, especially in the second half of October, is potentially problematic because clouds are frequently absent in that region.

The discrepancy between model and observation is largest near the coast, with the typical modeled MBL depth significantly shallower than satellite estimates. Moving west from the buoy, the models tend to deepen the boundary layer much more rapidly than MODIS and CALIPSO. To the west of $90^{\circ} \mathrm{W}$ the model consensus MBL depth agrees well with MODIS and CALIPSO, though not with COSMIC.

The tendency of GCMs to underestimate MBL depth at the stratus buoy has been noted in multiple studies (Bretherton et al., 2004; Hannay et al., 2009). It is unclear why GCMs and other models consistently underestimate this and why the underestimate is especially strong near the coast, though in 

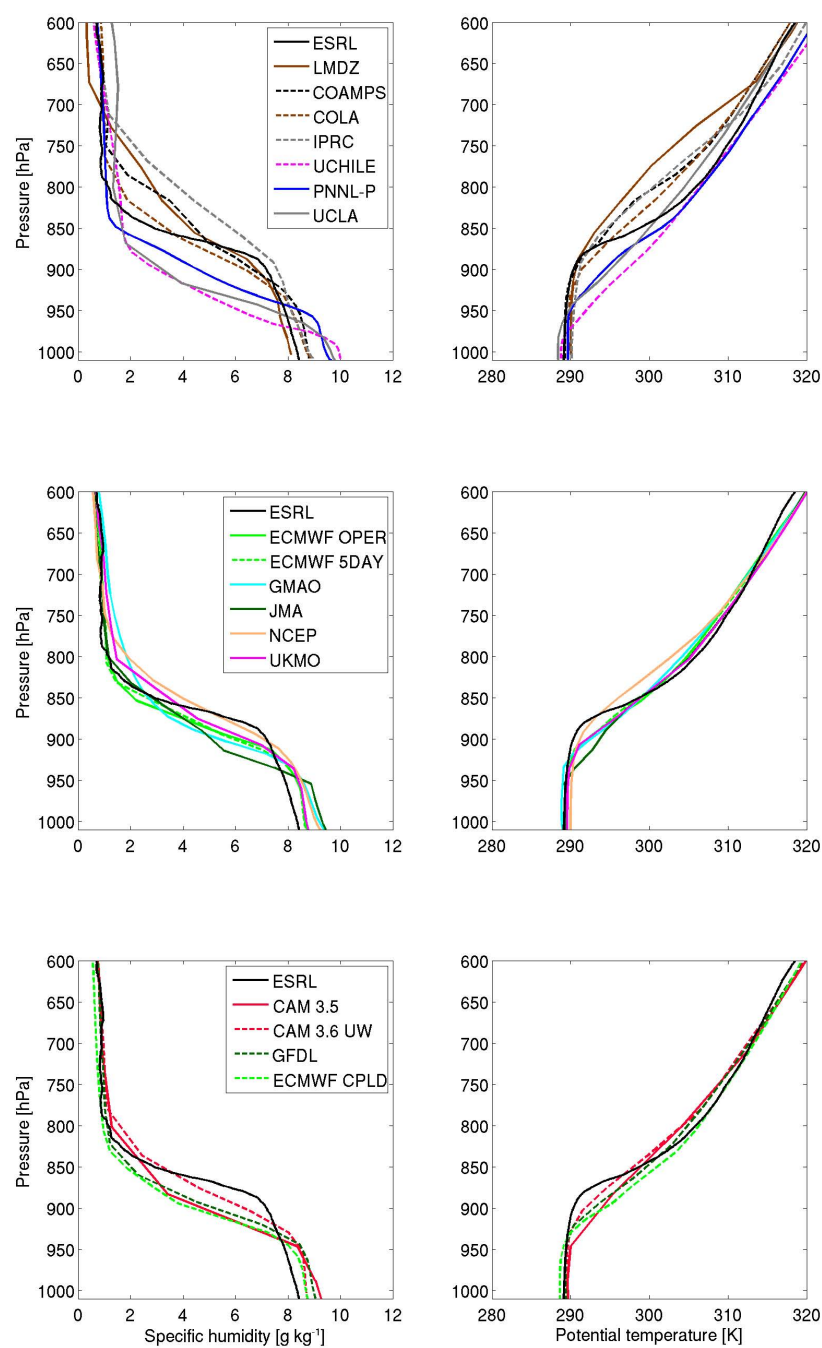

Fig. 8. Soundings of specific humidity (left, $\mathrm{kgkg}^{-1}$ ) and potential temperature (right, $\mathrm{K}$ ) at $20^{\circ} \mathrm{S} 85^{\circ} \mathrm{W}$. Model soundings are October 2006 means for regional (top), operational (middle) and climate (bottom). NOAA/ESRL soundings (black) are an average of several-day October periods in multiple years (see text).

the latter case the model under-resolution of topographic features may be to blame (R. Garreaud, personal communication, 2009).

\section{Diurnal cycle}

We next consider the mean October diurnal cycle in the vicinity of the stratus buoy. Figure 11 shows the composite diurnal cycle in LWP (averaged over cloudy and clear atmospheric columns) and low-cloud fraction of the models for a $1^{\circ} \times 1^{\circ}$ box centered on the buoy (hour 00:00 LT is 05:00 UTC). To compare with modeled and observed LWP (Fig. 11a), we have plotted a best fit sinusoid (black line) at the buoy over October 2006 from satellite data (L. O’Neill, personal com-

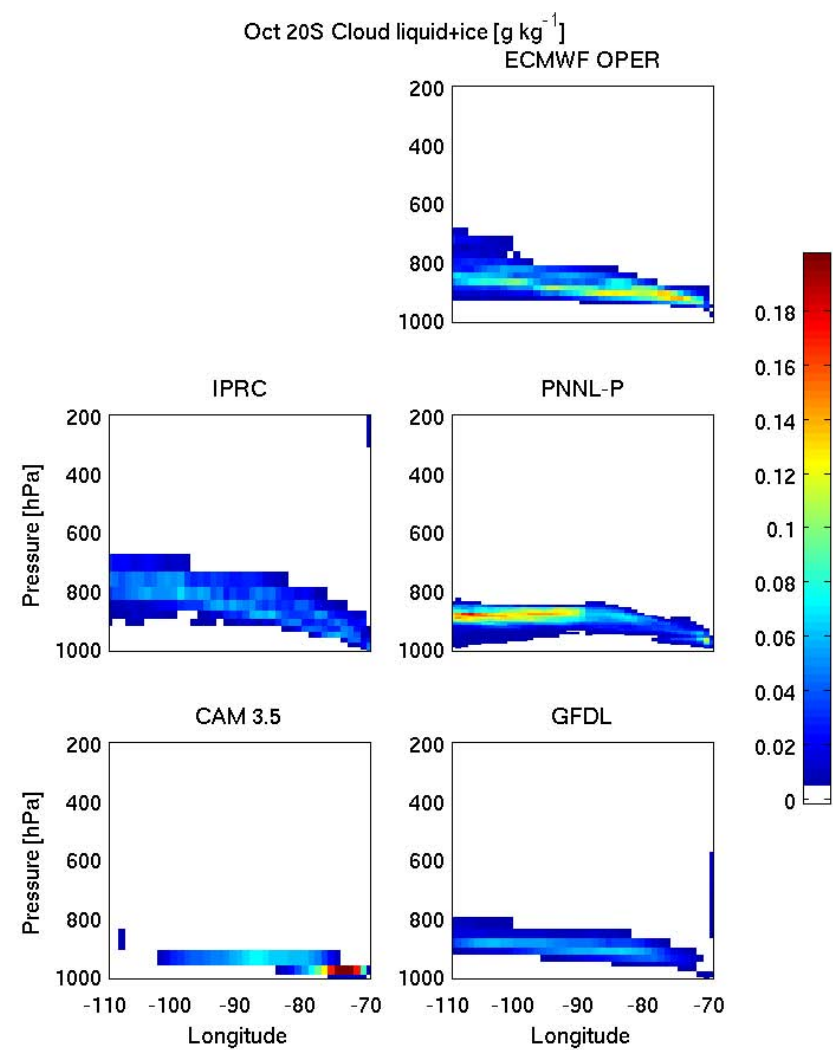

Fig. 9. October 2006 mean $20^{\circ} \mathrm{S}$ cross sections of model liquid water content $\left(\mathrm{gkg}^{-1}\right)$.

munication, 2009). The fit uses data from TMI, SSM/I, and AMSR-E, though the diurnal amplitude and phase effectively comes only from TMI. Most models have a weaker diurnal cycle in LWP than the observed at the buoy. However, when normalized by 24-h mean LWP, the amplitude of the models diurnal cycle compares well with the observed amplitude. For several models the discrepancy with observed LWP could be interpreted as an error in geographic placement of the maximum mean LWP; the mean observed TMI liquid water path (Fig. 5) is near its maximum at the buoy while many models have their maximum LWP further to the west or northwest (e.g. PNNL). The observed LWP peaks around 04:00-05:00 a.m. LT, consistent with the well-known diurnal radiative modulation of stratocumulus cloud thickness. For most models the phase of the LWP agrees fairly well with the observed phase.

The diurnal cycle of cloud fraction near the buoy is compared to observational climatologies in Fig. 11b. The Ghate et al. (2009) climatology of cloud fraction (thick black line) is derived from September-November (SON) measurements of downward longwave radiation made at the stratus buoy from 2001-2005. The Extended Edited Synoptic Cloud Reports Archive (EECRA) cloud fraction (thin black line) is based on 1956-1997 SON climatology of ship-based surface 


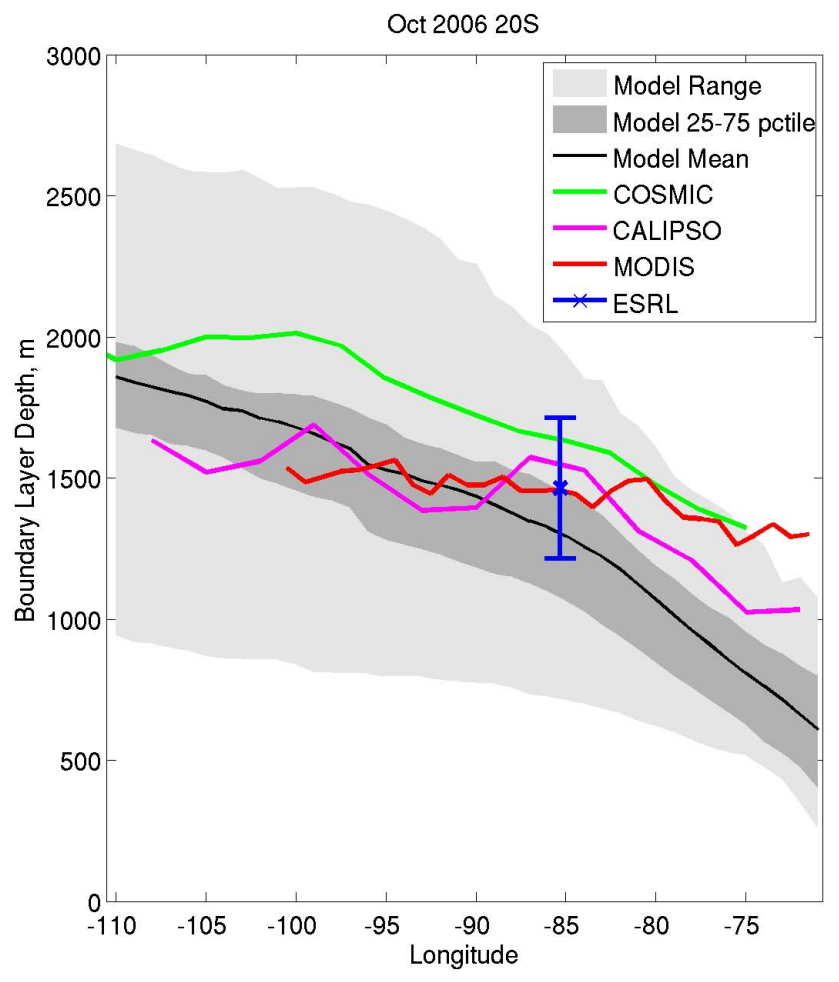

Fig. 10. October 2006 model boundary layer depth (m) compared with observations of boundary layer depth and cloud-top height. Model mean (solid black line), 25-75 percentile range (dark gray), and model range (light gray) are plotted. COSMIC October 2006 boundary layer depth sampled over $15-25^{\circ} \mathrm{S}$ is plotted in green. CALIPSO cloud-top height is plotted in magenta. MODIS cloudtop heights are plotted in red from Zuidema et al. (2009). The mean depth (blue $\mathrm{x}$ ) is an October climatology estimated from NOAA/ESRL soundings taken near the stratus buoy, with standard deviation plotted.

observations (Hahn and Warren, 1999) of whole-sky cover of clouds with cloud-base below $3000 \mathrm{ft}$. The diurnal mean of both of these measures is slightly higher than that of MODIS $(\sim 0.7$, Fig. 4$)$; this is due at least in part to differences in the definitions of cloud fraction. The model consensus cloud fraction near the buoy is much lower than any of these observational estimates.

The Ghate et al. (2009) cloud fraction, which has better resolution in time than the EECRA, shows a pronounced afternoon and early-evening drop. Many models also have strong afternoon cloud fraction reduction, though most of these same models also have a strong morning peak not present in the observations. The amplitudes of the models' diurnal cycle of low-cloud fraction range widely from about 0.04 to 0.6 . The strong mean diurnal cycle in LWP is therefore primarily an oscillation of cloud fraction in some models and of cloud thickness in others.

The significant disagreement in the amplitude of the diurnal cycle of cloudiness between EECRA reports and buoy (a)

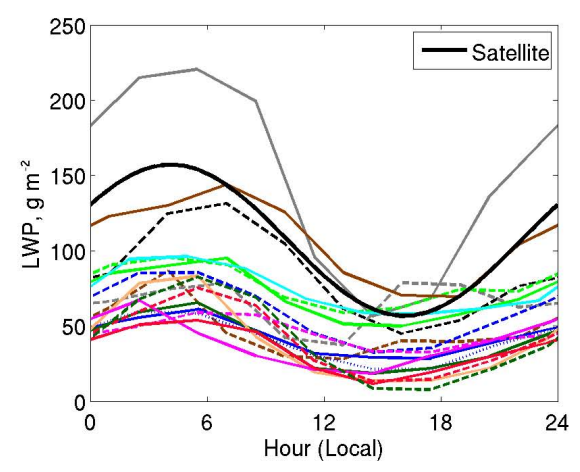

(b)

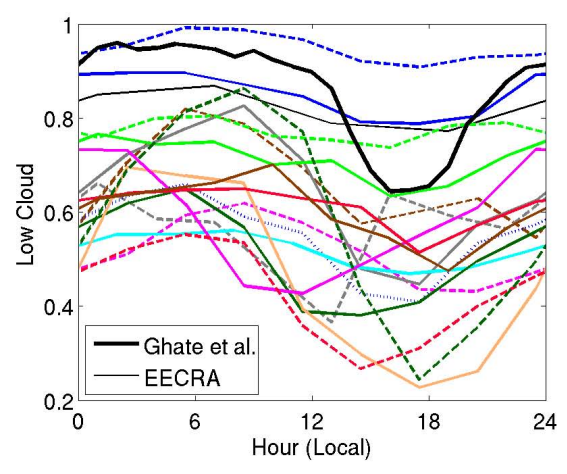

\begin{tabular}{|l|}
\hline$-\cdots--$ COAMPS \\
---- COLA \\
$-\cdots--$ IPRC \\
--- PNNL-M \\
\hline PNNL-P \\
PNNL-C \\
- UCHILE \\
UCLA \\
\hline ECMWF OPER \\
- ECMWF 5DAY
\end{tabular}

GMAO

- JMA

NCEP

UKMO

- CAM 3.5

---- CAM 3.6 UW

-----GFDL

- LMDZ

Fig. 11. Composite October 2006 diurnal cycle of (a) liquid water path $\left(\mathrm{gm}^{-2}\right)$ and (b) low cloud fraction at the IMET buoy at $85^{\circ} \mathrm{W}$ $20^{\circ} \mathrm{S}$. In (a) satellite observations from 2006 (see text) are plotted (thick black line) and in (b) observed climatologies of cloud fraction from the buoy (Ghate et al., 2009, thick black line) and EECRA (Hahn and Warren, 1999, thin black line) are plotted.

radiation measurements is significant but perhaps not entirely surprising because of the different methodologies used. It is therefore difficult to assess the realism of the models' diurnal cycle of low clouds.

Also of interest is the diurnal "upsidence" wave modeled in Garreaud and Munoz (2004). This wave of upward-motion in the lower troposphere is believed to be a response to diurnal heating over the Andes. In Fig. 12 we show the diurnal composite pressure velocity $\omega$ at $850 \mathrm{hPa}$ along $20^{\circ} \mathrm{S}$ in various models (hour 00:00 LT is 05:00 GMT). For most models (including those not shown), a clear westward propagating upsidence wave is present with a phase speed similar to the estimated $30 \mathrm{~ms}^{-1}$ reported in Garreaud and Munoz (2004) and the estimate of $25 \mathrm{~ms}^{-1}$ in Wood et al. (2009) from QuikSCAT-retrieved winds. In the figure, the white line is the phase of the wave maximum, assumed to be parallel to the Peruvian coast, projected on to $20^{\circ} \mathrm{S}$ assuming the wave travels southwestwards at $30 \mathrm{~ms}^{-1}$. This disturbance typically starts near the coast around 05:00 p.m. local time and reaches the stratus buoy around 02:00 a.m. LT. Of the models shown in Fig. 12, the wave is not pronounced 

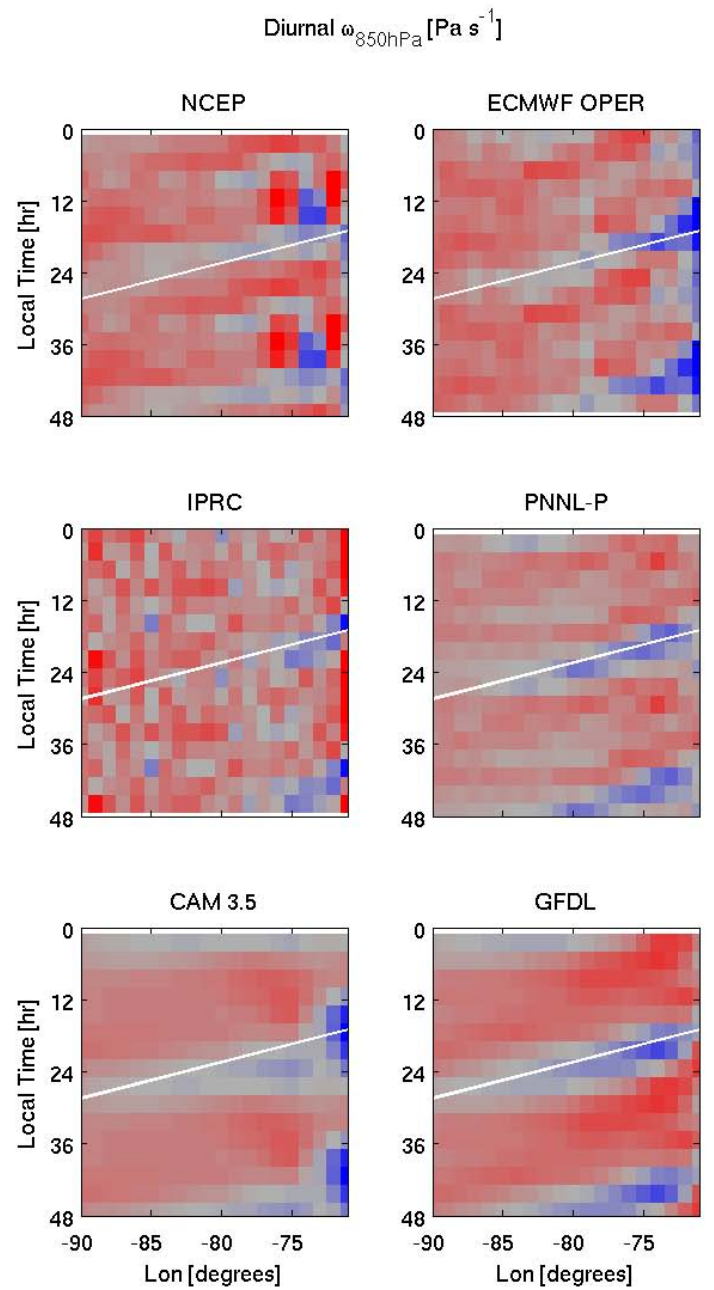

Fig. 12. Hovmüller diagram along $20^{\circ} \mathrm{S}$ of a 24-h composite (repeated twice for clarity) of omega at $850 \mathrm{hPa}\left(\mathrm{Pas}^{-1}\right)$ of selected models for October 2006. White line is phase speed of $30 \mathrm{~ms}^{-1}$.

in the NCEP and IPRC simulation, and rather weak in the CAM 3.5. While this upsidence wave appears to result in a slight boundary layer deepening $(\sim 50 \mathrm{~m})$ in models where it occurs, its effect on modeled cloud fraction and liquid water path appears to be small based on diurnal composites of these quantities at $20^{\circ} \mathrm{S}$ (not shown).

\section{Synoptic variability}

We next examine the daily variations by the models throughout the month of October 2006 associated with synoptic changes. We focus on $20^{\circ} \mathrm{S}$, which includes the NOAA/WHOI stratus cruises and was major focus of the $2008 \mathrm{REx}$ field campaign. South of $20^{\circ} \mathrm{S}$ there is significant synoptic activity, as austral springtime mid-latitude cyclones brush by every few days. To the north of $20^{\circ} \mathrm{S}$, the influence of these midlatitude systems is weak and a more static
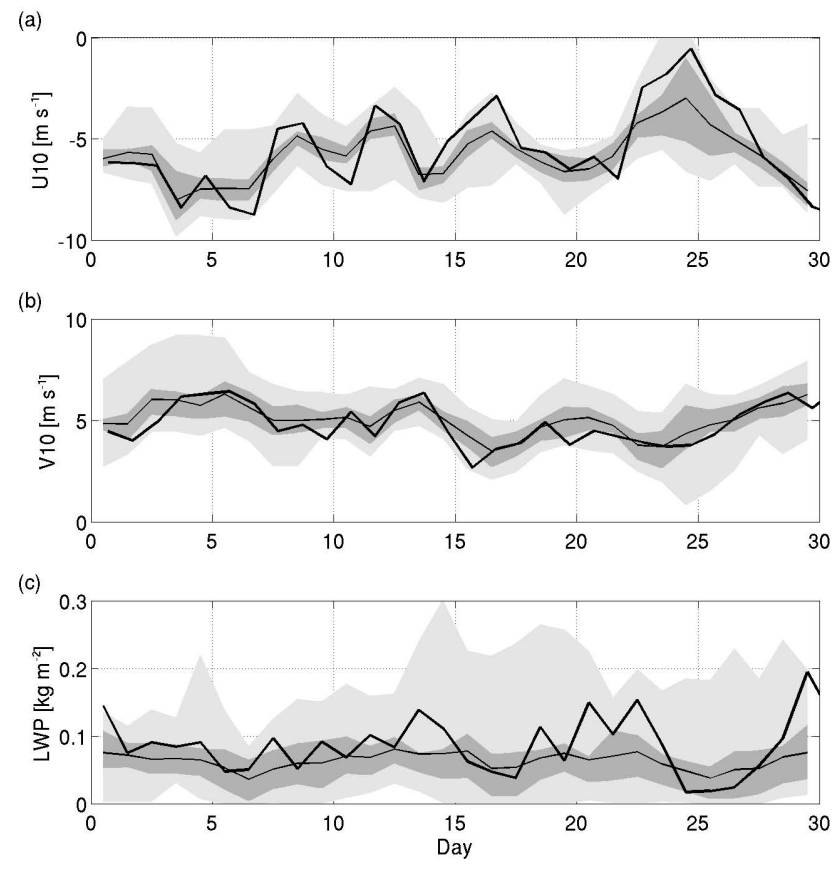

Fig. 13. Time series of 24-h averaged (a) 10-m zonal velocity $\left(\mathrm{ms}^{-1}\right)$, (b) $10-\mathrm{m}$ meridional velocity $\left(\mathrm{ms}^{-1}\right)$, and (c) liquid water path $\left(\mathrm{kgm}^{-2}\right)$ for a $3^{\circ} \times 3^{\circ}$ box centered at $20^{\circ} \mathrm{S} 85^{\circ} \mathrm{W}$. Model means (light black line), 25th-75th percentile range (dark gray), and model range (light gray) are plotted. Heavy black lines indicate observations; QuikSCAT in (a) and (b) and AMSR-E LWP in (c), respectively. Day 0 on the time axis corresponds to $0 \mathrm{Z}, 1$ October 2006.

dynamical regime is maintained albeit with substantial variations in cloudiness. Along $20^{\circ} \mathrm{S}$, muted effects of the higher latitude systems remain.

Figure 13a and $\mathrm{b}$ shows the daily-averaged modeled and QuikSCAT surface winds at the stratus buoy. The daily-mean u-component of the wind is easterly for the entire month of October, and its magnitude ranges from near 0 to $9 \mathrm{~ms}^{-1}$. The models generally capture the synoptic variability well, but overestimate the easterly component during the last half of the month compared with QuikSCAT. The v-component of the wind also blows from the same direction (southerly) for the entire month but exhibits substantially less synoptic variability than the u-component, with magnitudes only ranging from 3 to $6 \mathrm{~ms}^{-1}$. The LWP at the buoy (Fig. 13c) as measured by AMSR-E shows strong variations on day-today timescales that are not matched by the model consensus (Fig. 13c) or by individual models (not shown). The models LWP variations do not agree well with each other, and no particular model matches the AMSR-E LWP variations well.

The first row of Fig. 14 shows daily averaged observations of MODIS liquid cloud fraction and cloud-top height derived from MODIS (Zuidema et al., 2009). The white areas in cloud fraction indicate missing retrievals due to clearing 

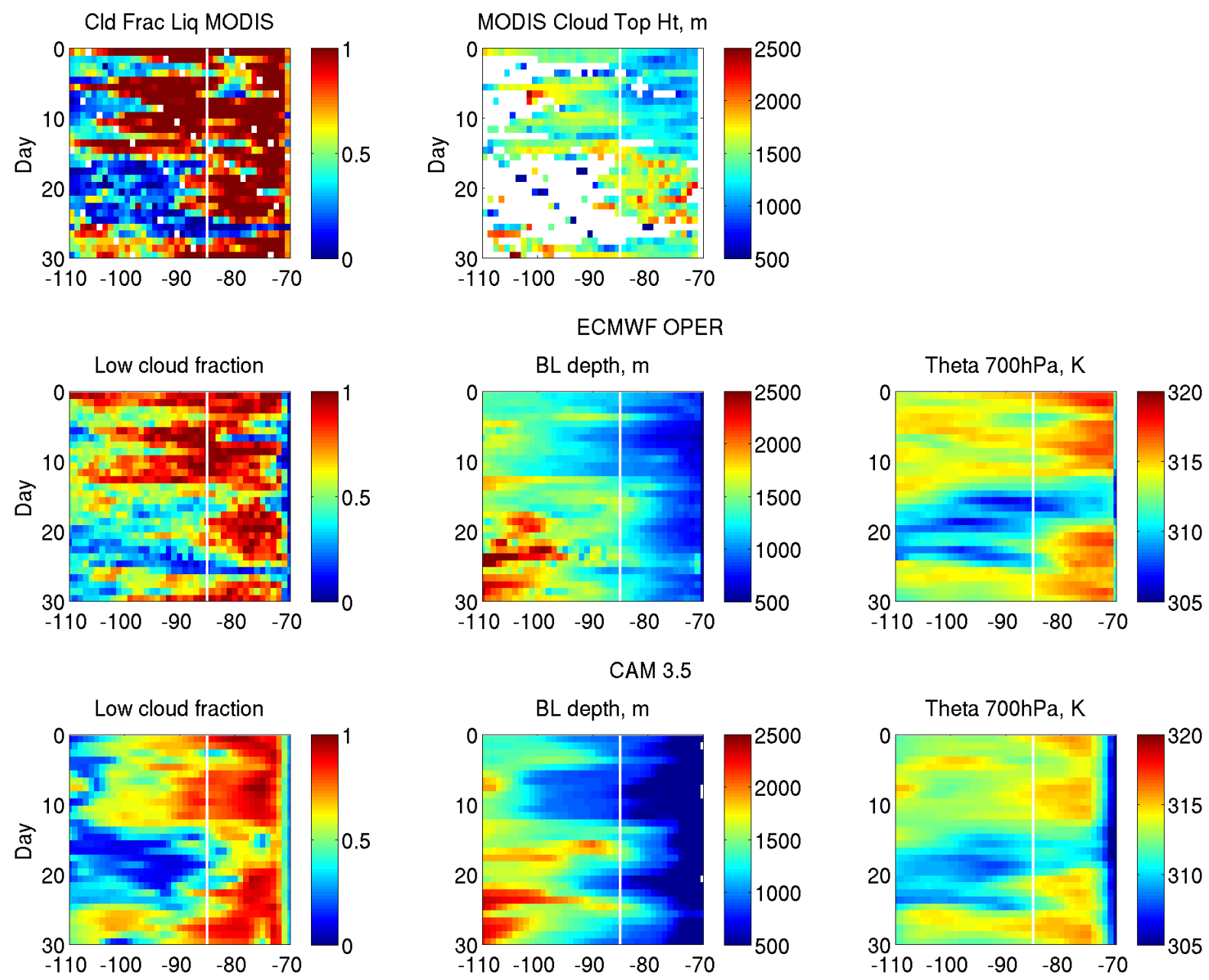

Fig. 14. Hovmüller diagrams of 24-h means along $20^{\circ} \mathrm{S}$ for October 2006. MODIS cloud fraction and cloud top height (m) are plotted in the top row. The bottom two rows are low cloud fraction, boundary layer depth (m), and potential temperature at $700 \mathrm{hPa}(\mathrm{K})$ for the ECMWF operational model and CAM 3.5, respectively. The white line indicates the stratus buoy position. All data are horizontally averaged over a $1^{\circ} \times 1^{\circ}$ box.

and the need for relatively homogeneous clouds to estimate MODIS cloud-top height. Plotted below are the low cloud fraction and MBL depth for the ECMWF operational model and for CAM 3.5. MODIS cloud fraction, dominated by low cloud, shows a dramatic drop in cloudiness to the west of the buoy starting at around day 15 and this clearing extending eastwards of the buoy at day 25 for a period of $2-3 \mathrm{~d}$ before widespread clouds are reestablished. MODIS cloud-top height retrievals show a broad deepening west of the buoy just before the day 15 clearing. At this time the boundary layer deepens significantly at the buoy and to its east. The extended period with deeper boundary layer appears to be associated with the reduction in cloud fraction.

The ECMWF operational model succeeds in capturing much of the $20^{\circ} \mathrm{S}$ cloud change during the comparison period, showing both a dramatic reduction in clouds at day 14 to the west of the buoy and the clearing to the east of it at day 25. The values of cloud fraction are more extreme in the MODIS data, and the main clearing starts slightly further westward, but the general cloudiness patterns are very well characterized. The ECMWF model also shows a widespread and persistent boundary layer deepening beginning at day 13 , though it has the typical model underestimate of boundarylayer depth east of the buoy. The observed negative temporal correlation between MBL depth and cloud fraction is also seen in the ECWMF operational model. CAM 3.5 also captures the main observed clearing and the boundary layer deepening just before it. It does not match the day 25 clearing near and to the east of the buoy, and has too little cloud in general to the west of the buoy, a problem also seen south of $20^{\circ} \mathrm{S}$ in the Fig. 4 .

The day 13 change to a deeper boundary layer in ECMWF and CAM is strongly tied to a $\sim 5-10 \mathrm{~K}$ cooling of the lower troposphere above the boundary layer, as can be seen in the 
modeled potential temperature at $700 \mathrm{hPa}$ in Fig. 13 (rightmost column). Associated with this cooling is above-MBL cooling to the south and southeast of the buoy (not shown), the primary directions from which the lower troposphere is advected. This cooling promotes stronger entrainment and deepening of the MBL.

Some aspects of these changes are captured by most of the models. Figure 15 shows time series of the MBL depth and cloud fraction for all of the models at the stratus buoy, diurnally averaged, together with MODIS observations (black solid line). (Each point represents a 24-h mean from 00:00 24:00 UTC). While there is scatter in the mean MBL depth, especially among regional models, all of the models show deepening at around day 13, and a deeper boundary layer tends to persist for a several day period. Interestingly this change is not as clear in the MODIS retrieval. Most operational models show some clearing associated with this change, while regional and climate model cloud changes are not consistent. The operational models also are able to better capture the observed clearing event at day 25 , an event which does not appear to be connected directly with boundary layer depth changes, but instead is related to strong increases in modeled subsidence (not shown).

\section{Discussion and conclusions}

The PreVOCA model assessment surveyed the ability of a wide range of contemporary atmospheric models to simulate the SEP region near the Chilean coast during October 2006. October in the SEP is characterized by extensive marine stratocumulus boundary layers and weak mean lowlevel subsidence. Operational and climate models performed daily short-term forecasts for the period, while regional models each ran month-long simulations forced continuously by analysis. Overall the models do a good job of simulating the observed anticyclonic surface winds. They share similar mean subsidence patterns, though these are difficult to evaluate by observational comparison. Meanwhile, the cloud and boundary layer properties produced by the models are quite diverse especially in cloud fraction, MBL depth, and LWP. Cloud fraction biases are primary contributors to very large biases in the downward shortwave flux at the surface.

The models also have widely varying MBL depths. A very common model problem to the east of the stratus buoy is the under-prediction of the MBL depth, especially near to the coast. This does not appear to be simply a problem of insufficient horizontal resolution (e.g., the ECMWF OPER model, with relatively fine $25-\mathrm{km}$ horizontal resolution, substantially underestimates coastal MBL depth at $20^{\circ} \mathrm{S}$ ). This problem has important implications for modeling of surface fluxes, cloud thickness, and cloud fraction, though there is no clear connection between mean MBL depth bias and mean cloud fraction bias among these models.

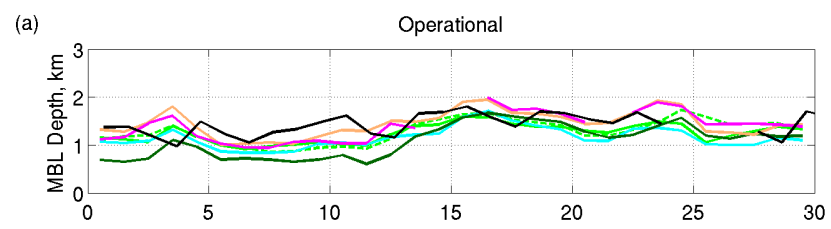

(b)

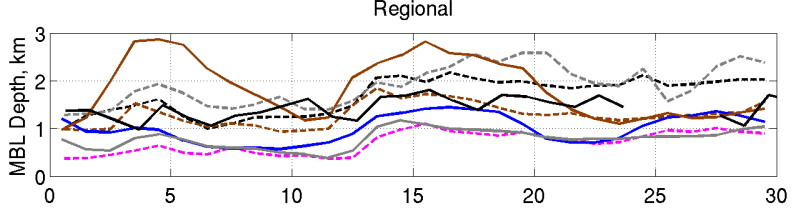

(c)
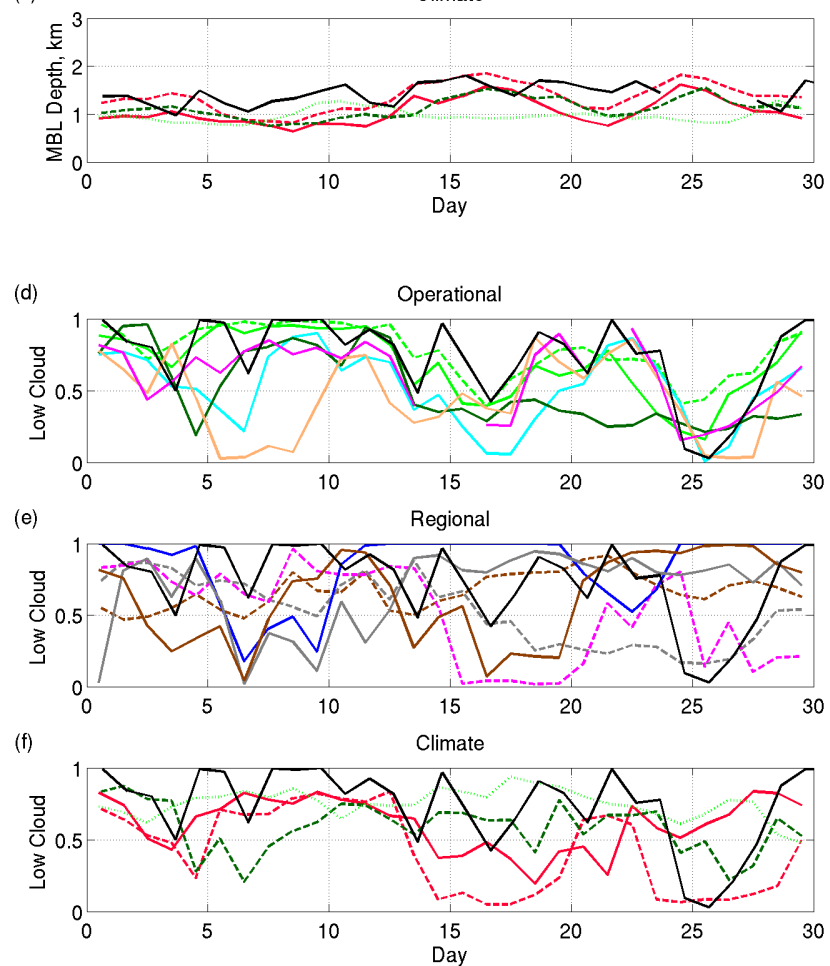

Fig. 15. October 2006 time series of 24-h mean boundary layer depth in $\mathrm{km}(\mathbf{a}-\mathbf{c})$ and low cloud fraction $(\mathbf{d}-\mathbf{f})$ for a $3^{\circ} \times 3^{\circ}$ box centered at $20^{\circ} \mathrm{S} 85^{\circ} \mathrm{W}$. Solid black lines are MODIS cloud-top height and MODIS cloud fraction. Model line types as in Fig. 8.

The models generally under-predict the amplitude of the diurnal cycle of liquid water path at the stratus buoy, though the amplitude relative to the mean LWP agrees fairly well. The models' predictions of the diurnal cycle of low-cloud fraction are quite varied, with several models predicting a significant peak in morning cloud fraction compared with more flat observations. Discrepancies in the observed diurnal cycle, especially in the size of the late afternoon/early evening drop in cloud fraction, make the evaluation of the diurnal model cloud fraction biases difficult. Hopefully these comparisons can be improved using the more extensive measurements available in VOCALS REx. 
Most models produce a diurnal upsidence wave which propagates southwestward with phase velocity similar to that reported in previous studies. Though the upsidence wave produces clear perturbations in MBL height as it passes, its effect on modeled offshore cloud fraction appears to be minimal in these models.

Most of the models qualitatively capture the large variations in MBL height associated with synoptic variability. The primary cause of these variations is the changing temperature above the boundary layer in the lower troposphere altering the LTS. The influence of variations of large-scale subsidence on MBL-height variations appears to be secondary to other conditions. At the stratus buoy, in observations and in some models, deepening of the MBL is associated with reduced cloudiness. For most models, however, low cloud changes do not agree with observed changes or with each other. Two forecast models in particular, ECMWF and UKMO, show skill at cloud prediction, whereas the regional models do not. There is not a clear relationship between model vertical resolution and model skill at predicting MBL height or cloud properties.

The differences in performance between the operational forecast models and the regional models are large. The operational model forecasts tend to agree well with one another in surface winds and MBL depth, more so than the regional models. Some of this difference in performance may be due to the short simulation length of the runs made in forecast mode. For all of the forecast-mode runs (all operational models runs plus CAM and GFDL), the whole domain is reinitialized with analysis for each run, reducing errors and drift from analyzed states. In contrast the regional models are initialized only once, and the observational analysis that is applied at the boundaries can take days to influence the entire study region. The operational models also benefit because the analyses they use are often created by models with identical or nearly identical physics, so model adjustments to the boundary conditions are greatly reduced. Despite these advantages, many of the operational forecast models have substantial deficiencies in predicting cloud properties.

The simulations in this study do not have the necessary horizontal resolution to accurately simulate pockets of open cells (POCs), which are a significant observed feature of low clouds in the region. For regional and global models in the foreseeable future, parameterizations for POCs will likely be necessary to accurately represent cloud cover in this and similar regions.

A major focus of VOCALS is the interaction between aerosols and clouds, and the cloud and boundary-layer modeling errors demonstrated here pose substantial challenges to modeling aerosol and gas concentrations and transport, as well as aerosol source and sink processes. A follow-on intercomparison of a similar suite of models during for OctoberNovember 2008 during REx will be performed with a particular focus on aerosol-cloud interactions. This future study, the VOCALS Assessment or VOCA, will benefit from a large array of in-situ aircraft and ship measurements, and will no doubt provide further insights to improve modeling of this region.

\section{Appendix A}

Here we provide a description of the model physics and experiment setup in more detail. Unless otherwise stated, all the models use single moment bulk microphysical schemes. Of the models that use aerosols, most use climatological specified aerosol concentrations which impact the simulations through radiative effects only. Exceptions will be noted below.

COAMPS - The Coupled Ocean/Atmosphere Mesoscale Prediction System of the Naval Research Laboratory (Hodur, 1997 ) is run for $24 \mathrm{~h}$ periods, twice daily starting at $0: 00 \mathrm{Z}$ and $12: 00 \mathrm{Z}$ with a smaller nested grid covering the study region. It continuously assimilates atmospheric and SST data. It uses the Navy Operational Global Atmospheric Prediction System (NOGAPS) global model to provide lateral boundary conditions. A moist TKE scheme is used in the PBL. A bulk microphysics scheme based on Rutledge and Hobbs (1984) is used.

COLA - The submission from the Center for OceanLand-Atmosphere Studies uses the Regional Spectral Model (RSM) developed at the Experimental Climate Prediction Center (ECPC) of the Scripps Institution of Oceanography described in Kanamaru and Kanamitsu (2007) with some modifications, particularly to the treatment of cloudwater. A month long simulation was performed, continuously forced by NCEP/NCAR reanalysis. The model uses the non-local PBL scheme of Hong and Pan (1996), bulk cloud microphysics (Sundqvist et al., 1989), and the prognostic cloud water scheme of Zhao and Carr (1997).

ECMWF - Several ECMWF model results were submitted, three of which we show here. The operational model (ECMWF-OPER) uses ECMWF-IFS CY31R1; the five day forecasts runs (ECMWF-5DAY) are using CY32R3. The coupled ensemble forecasts (ECMWF-CPLD) are using CY32R3 run eyx6. These models have very similar physical parameterizations, but the CY32R3 runs include refinements to convection and stratocumulus representation and the introduction of McICA radiation. The ECMWF ECMWF5DAY runs were initialized with the ECMWF analysis. The coupled 5-member ensemble runs were initialized on $1 \mathrm{Au}-$ gust 2006 with differing initial perturbations and the output shown here are ensemble means. The model runs all use a combined eddy diffusivity-mass-flux scheme using moist conserved variables for the dry and stratocumulus-topped boundary layer (Köhler, 2005; Tiedtke, 1993) microphysics.

GFDL - The Geophysical Fluid Dynamics Laboratory (GFDL) AM2 model (GFDL-GAMDT, 2004) was run with a finite volume dynamical core on a cubed-sphere grid. Each 00:00 Z daily forecast was initialized with ECMWF analysis 
data (identical to that used for CAM). A Lock et al. (2000) Kprofile boundary layer scheme with calculated entrainment rate was used and the bulk microphysics scheme of Rotstayn (1997) was used.

IPRC - The International Pacific Research Center IPRCRegCM (Wang et al., 2003, 2004) version 1.2 was run continuously throughout the study period with the lateral boundaries forced with NCEP/NCAR reanalysis. The model uses a prognostic TKE scheme with an additional non-local flux parameterization and a bulk mixed-phase Lin-type microphysical scheme (Wang, 2001). An artificial smoothlyvarying cloud-droplet concentration is specified over the ocean based upon proximity to land.

JMA - The Japan Meteorological Agency model, version GSM0711 was run as a series of $4 \times$ daily forecasts, each run for $30 \mathrm{~h}$, with the last $6 \mathrm{~h}$ analyzed here. Each run was initialized from JMA operational global analysis. The model uses a Mellor-Yamada level-2 PBL scheme and has a bulk microphysics scheme based on Sundqvist (1978) and Sundqvist et al. (1989).

LMDZ - The LMDZ general circulation model from the Laboratoire de Meterologie Dynamique (Hourdin et al., 2006) has no active microphysics scheme in the runs presented here. Runs were submitted using both the default K-profile turbulent scheme and a new boundary MellorYamada type boundary layer scheme with a moist thermal plume scheme. We present here runs with the newer boundary layer-scheme only; the other scheme did not produce strongly different results. The month was run continuously with a fine grid over the study region and relaxation to ERA40 winds outside of the fine grid. No other variables were relaxed towards reanalysis.

NASA GMAO - The Global Modeling and Assimilation Office (GMAO) GEOS-5 DAS output comes from a $4 \times$ daily forecasts with global data assimilation. The model uses a Lock et al. (2000) boundary layer scheme and a Sundqvisttype bulk microphysics scheme.

NCAR - Two versions of the National Center for Atmospheric Research Community Atmospheric Model (CAM, Collins et al., 2004) were used. For each version, three day simulations were run initialized from daily 00:00 Z ECMWF analysis, with results from the third day presented here. The first version, CAM 3.5 uses a non-local K-profile boundary layer scheme (Holtslag and Boville, 1993) and a single moment bulk microphysics scheme (Rasch and Kristjansson, 1998). The second version, CAM 3.6 UW is run using a prognostic TKE scheme (see Bretherton and Park, 2008) and the shallow convection scheme of Park and Bretherton (2009). CAM 3.6 runs use the double-moment bulk microphysical scheme with prognostic cloud-droplet number concentration of Morrison and Gettelman (2008) which allows aerosol concentration to affect cloud droplet activation. Both versions have prognostic aerosols and use the MOZART bulk aerosol model (Lamarque et al., 2005).
NCEP - The National Centers for Environmental Prediction Global Forecasting System (GFS) model operational runs use the NCEP data initialization system for initial conditions. A non-local surface-forced K-profile scheme is used for the PBL. The bulk microphysics scheme of Zhao and Carr (1997) used.

PNNL - The WRF-Chem model version 2.2 was run in a number of configurations with both an inner nested domain and an outer domain. We present here the runs which include a high resolution domain from $10-30^{\circ} \mathrm{S}$ and from 70 $90^{\circ} \mathrm{W}$ nested within a coarser outer domain. The output presented here is from the outer domain. The initial and boundary conditions are based on GFS analysis. The PBL scheme is YSU (Hong et al., 2006) and the microphysics used is a Lin scheme (Lin et al., 1983; Chen and Sun, 2002) modified to make autoconversion dependent on droplet number based on Liu et al. (2005). Three different categories of runs are presented, specified cloud droplet number concentration (PNNL-M), prognostic cloud-droplet number concentration but constant CNN concentration (PNNL-P), and interactive CNN with full chemistry, variable $\mathrm{CCN}$, and specified emissions of aerosols, $\mathrm{SO}_{2}$ and other gases (PNNL-C, Chapman et al., 2009).

UCHILE - The University of Chile runs use the WRF model (Skamarock et al., 2005), version 2.2 run continuously over October 2006 with NCEP/NCAR reanalysis for initial and lateral boundary conditions. It uses a prognostic MellorYamada-Janjić TKE scheme (Janjić, 2002) with a Lin microphysical scheme (Lin et al., 1983; Chen and Sun, 2002).

UCLA - The UCLA runs also use WRF 2.2 initialized and forced at the lateral boundaries by NCEP/NCAR reanalysis. A finer domain is nested within a coarser outer domain, with $15 \mathrm{~km}$ horizontal resolution for the inner domain. Output for the run is presented here from the inner domain. The YSU PBL scheme is used with explicitly treatment of entrainment at the PBL top. The WSM bulk microphysics scheme (Hong et al., 2004) is used.

UKMO - The Met Office Unified Model (MetUM) was run in its operational global model cycle G41 configuration. The dynamics is a non-hydrostatic two-time level semiimplicit, semi-Lagrangian formulation (Davies et al., 2005). The boundary layer scheme is a nonlocal surface-forced Kprofile scheme (Lock et al., 2000; Martin et al., 2000), the microphysics scheme is that of Wilson and Ballard (1999) and the cloud fraction scheme is that of Smith (1990). For more details of the model formulation and recent changes see Allan et al. (2007).

Acknowledgements. Thanks to D. Painemal and P. Zuidema for providing MODIS retrieved cloud-top heights. Also thanks to S. Park who provided his gridded EECRA data. COSMIC data was provided by B. Kuo. Many thanks to L. O'Neill at NRL who provided diurnal fits and monthly mean of LWP from satellite. CALIPSO cloud top-height data was provided by $\mathrm{D}$. Wu of the Ocean University of China. Thanks also to Virendra Ghate for providing diurnal cloud fraction data. QuikSCAT data are 
produced by Remote Sensing Systems and sponsored by the NASA Ocean Vector Winds Science Team. S. deSzoeke's archive of ship observations was very helpful to this work. The ISCCP FD data were obtained from the ISCCP web site http://isccp.giss.nasa.gov maintained at NASA GISS. S. A. Klein acknowledges M. Zhao (GFDL) for performing GFDL model integrations, J. Boyle (LLNL) for preparing analysis data, and the U. S. Department of Energy's Office of Science Climate Change Prediction and Atmospheric Radiation Measurement programs for financial support. The contribution of S. A. Klein to this work is performed under the auspices of the US Department of Energy by Lawrence Livermore National Laboratory under contract DE-AC52-07NA27344. We acknowledge the support of NASA award No. NX06AB74G for C. Hannay. This work was also supported by NSF grant ATM0745702 and NOAA grant NA070AR4310282.

Edited by: J. Quaas

\section{References}

Allan, R., Slingo, A., Milton, S., and Brooks, M.: Evaluation of the Met Office global forecast model using geostationary Earth Radiation Budget (GERB) data, Q. J. Roy. Meteor. Soc., 133, 1993-2010, 2007.

Anthes, R., Bernhardt, P., Chen, Y., Cucurull, L., Dymond, K., Ector, D., Healy, S., Ho, S., Hunt, D., Kuo, Y., Liu, H., Manning, K., Mccormick, C., Meehan, T., Randel, W., Rocken, C., Schreiner, W., Sokolovskiy, S., Syndergaard, S., Thompson, D., Trenberth, K., Wee, T., Yen, N., and Zeng, Z.: The COSMIC/FORMOSAT-3 - Mission early results, B. Am. Meteorol. Soc., 89, 313-333, 2008.

Boyle, J., Klein, S., Zhang, G., Xie, S., and Wei, X.: Climate model forecast experiments for TOGA COARE, Mon. Weather Rev., 136, 808-832, 2008.

Bretherton, C. and Park, S.: A new bulk shallow-cumulus model and implications for penetrative entrainment feedback on updraft buoyancy, J. Atmos. Sci., 65, 2174-2193, 2008.

Bretherton, C., Uttal, T., Fairall, C., Yuter, S., Weller, R., Baumgardner, D., Comstock, K., Wood, R., and Raga, G.: The EPIC 2001 stratocumulus study, B. Am. Meteorol. Soc., 85, 967-977, 2004.

Chapman, E. G., Gustafson Jr., W. I., Easter, R. C., Barnard, J. C., Ghan, S. J., Pekour, M. S., and Fast, J. D.: Coupling aerosolcloud-radiative processes in the WRF-Chem model: Investigating the radiative impact of elevated point sources, Atmos. Chem. Phys., 9, 945-964, doi:10.5194/acp-9-945-2009, 2009.

Chen, S. and Sun, W.: A one-dimensional time dependent cloud model, J. Meteorol. Soc. Jpn., 80, 99-118, 2002.

Colbo, K. and Weller, R.: The variability and heat budget of the upper ocean under the Chile-Peru stratus, J. Mar. Res., 65, 607637, 2007.

Collins, W., Rasch, P., Boville, B., Hack, J., McCaa, J., Williamson, D., Kiehl, J., Briegleb, B., Bitz, C., Lin, S.-J., Zhang, M., and Dai, Y.: Description of the NCAR Community Atmosphere Model (CAM 3.0), Tech. rep., NCAR, 2004.

Davies, T., Cullen, M., Malcolm, A., Mawson, M., Staniforth, A., White, A., and Wood, N.: A new dynamical core for the Met Office's global and regional modelling of the atmosphere, Q. J. Roy. Meteor. Soc., 131, 1759-1782, 2005. de Szoeke, S., Fairall, C., and Pezoa, S.: Ship observations of the tropical Pacific Ocean along the coast of South America, J. Climate, 22, 458-464, 2009.

Field, P. and Wood, R.: Precipitation and cloud structure in midlatitude cyclones, J. Climate, 20, 5208-5210, 2007.

Garreaud, R. and Munoz, R.: The diurnal cycle in circulation and cloudiness over the subtropical southeast Pacific: A modeling study, J. Climate, 17, 1699-1710, 2004.

Garreaud, R., Rutllant, J., Quintana, J., Carrasco, J., and Minnis, P.: CIMAR-5: A snapshot of the lower troposphere over the subtropical southeast Pacific, B. Am. Meteorol. Soc., 82, 2193-2207, 2001.

GFDL-GAMDT: The new GFDL global atmosphere and land model AM2-LM2, J. Climate, 17, 4641-4673, 2004.

Ghate, V., Albrecht, B., Fairall, C., and Weller, R.: Climatology of surface meterology, surface fluxes, cloud fraction, and radiative forcing over the south-east Pacific from buoy observations, J. Climate, 22, 5527-5540, 2009.

Hahn, C. and Warren, S.: Extended edited synoptic cloud reports from ships and land stations over the globe, 1952-1996, Tech. rep., Carbon Dioxide Informational Analysis Center, Oak Ridge National Laboratory, 1999.

Hannay, C., Williamson, D., Hack, J., Kiehl, J., Olson, J., Klein, S., Bretherton, C., and Köhler, M.: Evaluation of forecasted southeast pacific stratocumulus in the NCAR, GFDL, and ECMWF Models, J. Climate, 22, 2871-2889, 2009.

Hodur, R.: The Naval Research Laboratory's coupled ocean/atmosphere mesoscale prediction system (COAMPS), Mon. Weather Rev., 125, 1414-1430, 1997.

Holtslag, A. and Boville, B.: Local versus nonlocal boundary-layer diffusion in a global climate model, J. Climate, 6, 1825-1842, 1993.

Hong, S. and Pan, H.: Nonlocal boundary layer vertical diffusion in a Medium-Range Forecast Model, Mon. Weather Rev., 124, 2322-2339, 1996.

Hong, S., Dudhia, J., and Chen, S.: A revised approach to ice microphysical processes for the bulk parameterization of clouds and precipitation, Mon. Weather Rev., 132, 103-120, 2004.

Hong, S., Noh, Y., and Dudhia, J.: A new vertical diffusion package with an explicit treatment of entrainment processes, Mon. Weather Rev., 134, 2318-2341, 2006.

Hourdin, F., Musat, I., Bony, S., Braconnot, P., Codron, F., Dufresne, J., Fairhead, L., Filiberti, M., Friedlingstein, P., Grandpeix, J., Krinner, G., Levan, P., Li, Z., and Lott, F.: The LMDZ4 general circulation model: climate performance and sensitivity to parametrized physics with emphasis on tropical convection, Clim. Dynam., 27, 787-813, 2006.

Janjić, Z.: Nonsingular implementation of the Mellor-Yamada level 2.5 scheme in the NCEP Meso model., Tech. rep., NCEP, 2002.

Kalnay, E., Kanamitsu, M., Kistler, R., Collins, W., Deaven, D., Gandin, L., Iredell, M., Saha, S., White, G., Woollen, J., Zhu, Y., Chelliah, M., Ebisuzaki, W., Higgins, W., Janowiak, J., Mo, K., Ropelewski, C., Wang, J., Leetmaa, A., Reynolds, R., Jenne, R., and Joseph, D.: The NCEP/NCAR 40-year reanalysis project, B. Am. Meteorol. Soc., 77, 437-471, 1996.

Kanamaru, H. and Kanamitsu, M.: Scale-selective bias correction in a downscaling of global analysis using a regional model, Mon. Weather Rev., 135, 334-350, 2007.

Klein, S. and Hartmann, D.: The seasonal cycle of low stratiform 
clouds, J. Climate, 6, 1587-1606, 1993.

Klein, S., Jiang, X., Boyle, J., Malyshev, S., and Xie, S.: Diagnosis of the summertime warm and dry bias over the U.S. Southern Great Plains in the GFDL climate model using a weather forecasting approach, Geophys. Res. Lett., 33, L18805, doi:10.1029/2006GL027567, 2006.

Köhler, M.: Improved prediction of boundary layer clouds, ECMWF Newsletter, 104, 18-22, 2005.

Lamarque, J., Kiehl, J., Brasseur, G., Butler, T., Cameron-Smith, P., Collins, W., Collins, W., Granier, C., Hauglustaine, D., Hess, P., Holland, E., Horowitz, L., Lawrence, M., McKenna, D., Merilees, P., Prather, M., Rasch, P., Rotman, D., Shindell, D., and Thornton, P.: Assessing future nitrogen deposition and carbon cycle feedback using a multimodel approach: Analysis of nitrogen deposition, J. Geophys. Res., 110, D19303, doi:10.1029/2005JD005825, 2005.

Lin, Y., Farley, R., and Orville, H.: Bulk parameterization of the snow field in a cloud model, J. Clim. Appl. Meteorol., 22, 10651092, 1983.

Liu, X., Penner, J., and Herzog, M.: Global modeling of aerosol dynamics: Model description, evaluation, and interactions between sulfate and nonsulfate aerosols, J. Geophys. Res., 110, D18206, doi:10.1029/2004JD005674, 2005.

Lock, A., Brown, A., Bush, M., Martin, G., and Smith, R.: A new boundary layer mixing scheme. Part I: Scheme description and single-column model tests, Mon. Weather Rev., 128, 3187-3199, 2000.

Ma, C., Mechoso, C., Robertson, A., and Arakawa, A.: Peruvian stratus clouds and the tropical Pacific circulation: A coupled ocean-atmosphere GCM study, J. Climate, 9, 1635-1645, 1996.

Martin, G., Bush, M., Brown, A., Lock, A., and Smith, R.: A new boundary layer mixing scheme. Part II: tests in climate and mesoscale models, Mon. Weather Rev., 128, 3200-3217, 2000.

Morrison, H. and Gettelman, A.: A new two-moment bulk stratiform cloud microphysics scheme in the community atmosphere model, version 3 (CAM3). Part I: Description and numerical tests, J. Climate, 21, 3642-3659, 2008.

Park, S. and Bretherton, C.: The University of Washington shallow convection and moist turbulence schemes and their impact on climate simulations with the community atmosphere model, J. Climate, 22, 3449-3469, 2009.

Phillips, T., Potter, G., Williamson, D., Cederwall, R., Boyle, J., Fiorino, M., Hnilo, J., Olson, J., Xie, S., and Yio, J.: Evaluating parameterizations in general circulation models - climate simulation meets weather prediction, B. Am. Meteorol. Soc., 85, 1903-1915, 2004.

Rasch, P. and Kristjansson, J.: A comparison of the CCM3 model climate using diagnosed and predicted condensate parameterizations, J. Climate, 11, 1587-1614, 1998.

Raymond, D., Esbensen, S., Paulson, C., Gregg, M., Bretherton, C., Petersen, W., Cifelli, R., Shay, L., Ohlmann, C., and Zuidema, P.: EPIC2001 and the coupled ocean-atmosphere system of the tropical East Pacific, B. Am. Meteorol. Soc., 85, 1341-1354, 2004.

Richter, I. and Mechoso, C.: Orographic influences on the annual cycle of Namibian stratocumulus clouds, Geophys. Res. Lett., 31, L24108, doi:10.1029/2004GL020814, 2004.

Richter, I. and Mechoso, C.: Orographic influences on subtropical stratocumulus, J. Atmos. Sci., 63, 2585-2601, 2006.

Rotstayn, L.: A physically based scheme for the treatment of strat- iform clouds and precipitation in large-scale models. 1. Description and evaluation of the microphysical processes, Q. J. Roy. Meteor. Soc., 123, 1227-1282, 1997.

Rutledge, S. and Hobbs, P.: The mesoscale and microscale structure and organization of clouds and precipitation in midlatitude cyclones. XII: A diagnostic modeling study of precipitation development in narrow cold-frontal rainbands, J. Atmos. Sci., 41, 2949-2972, 1984.

Skamarock, W., Klemp, J., Dudhia, J., Gill, D., Barker, D., Wang, W., and Powers, J.: A description of the advanced research WRF version 2, Tech. rep., NCAR, 2005.

Siebesma, A. P., Jakob, C., Lenderink, G., Neggers, R. A. J., Teixeira, J., Van Meijgaard, E., Calvo, J., Chlond, A., Grenier, H., Jones, C., Kohler, M., Kitagawa, H., Marquet, P., Lock, A. P., Muller, F., Olmeda, D., and Severijns, C.: Cloud representation in general-circulation models over the northern Pacific Ocean: A EUROCS intercomparison study, Q. J. Roy. Meteor. Soc., 130, 3245-3267, 2004.

Smith, R.: A scheme for predicting layer clouds and their watercontent in a general-circulation model, Q. J. Roy. Meteor. Soc., 116, 435-460, 1990.

Sundqvist, H.: Parameterization scheme for non-convective condensation including prediction of cloud water-content, Q. J. Roy. Meteor. Soc., 104, 677-690, 1978.

Sundqvist, H., Berge, E., and Kristjansson, J.: Condensation and cloud parameterization studies with a mesoscale numerical weather prediction model, Mon. Weather Rev., 117, 1641-1657, 1989.

Tiedtke, M.: Representation of clouds in large-scale models, Mon. Weather Rev., 121, 3040-3061, 1993.

Wang, Y.: An explicit simulation of tropical cyclones with a triply nested movable mesh primitive equation model: TCM3. Part I: Model description and control experiment, Mon. Weather Rev., 129, 1370-1394, 2001.

Wang, Y., Sen, O., and Wang, B.: A highly resolved regional climate model (IPRC-RegCM) and its simulation of the 1998 severe precipitation event over China. Part I: Model description and verification of simulation, J. Climate, 16, 1721-1738, 2003.

Wang, Y., Xie, S., Xu, H., and Wang, B.: Regional model simulations of marine boundary layer clouds over the southeast Pacific off South America. Part I: Control experiment, Mon. Weather Rev., 132, 274-296, 2004.

Williamson, D. and Olson, J.: A comparison of forecast errors in CAM2 and CAM3 at the ARM Southern Great Plains site, J. Climate, 20, 4572-4585, 2007.

Wolf, J.-O., Maier-Reimer, E., and Legutke, S.: The Hamburg Ocean Primitive Equation Model, Tech. rep., Deutsches Klimarechenzentrum, 1997.

Wood, R. and Hartmann, D.: Spatial variability of liquid water path in marine low cloud: The importance of mesoscale cellular convection, J. Climate, 19, 1748-1764, 2006.

Wood, R., Bretherton, C., and Hartmann, D.: Diurnal cycle of liquid water path over the subtropical and tropical oceans, Geophys. Res. Lett., 29, 2092, doi:10.1029/2002GL015371, 2002.

Wood, R., Köhler, M., Bennartz, R., and O'Dell, C.: The diurnal cycle of surface divergence over the global oceans, Q. J. Roy. Meteor. Soc., 135, 1484-1493, 2009.

Wu, D., Hu, Y., McCormick, M., Xu, K., Liu, Z., Smith, B., Omar, A., and Chang, F.: Deriving marine-boundary-layer lapse rate 
from collocated CALIPSO, MODIS, and AMSR-E data to study global low-cloud height statistics, Geosci. Remote Sens. Lett., 5, 649-652, 2008.

Xu, H., Wang, Y., and Xie, S.: Effects of the Andes on eastern Pacific climate: A regional atmospheric model study, J. Climate, 17, 589-602, 2004.

Xu, H., Xie, S., and Wang, Y.: Subseasonal variability of the southeast Pacific stratus cloud deck, J. Climate, 18, 131-142, 2005.
Zhang, Y., Rossow, W., Lacis, A., Oinas, V., and Mishchenko, M.: Calculation of radiative fluxes from the surface to top of atmosphere based on ISCCP and other global data sets: Refinements of the radiative transfer model and the input data, J. Geophys. Res., 109, D19105, doi:10.1029/2003JD004457, 2004.

Zhao, Q. and Carr, F.: A prognostic cloud scheme for operational NWP models, Mon. Weather Rev., 125, 1931-1953, 1997.

Zuidema, P., Painemal, D., de Szoeke, S., and Fairall, C.: Stratocumulus cloud-top height estimates and their climatic implications, J. Climate, 22, 4652-4666, 2009. 